\title{
Developments in salt-velocity flow measurement
}

\section{Un nouvel appareillage pour le jaugeage des débits par écran salé (méthode Allen)}

\author{
par Leslie YOUNG et G. WIIASON \\ NATIONAL ENGINERING LABORATORY, CAST KILBRTDE GLASGOW
}

\begin{abstract}
An extensive series of laboratory experiments, supplemented by field tests, has been made on the salt-velocity method of flow measurement. Comparative flow measurements were made by a standard weighbridge in the laboratory, and by current meters in the field tests. Novel apparatus has been constructed which is small and light for easy transport in field work, which will give satisfactory results in water of high initial conductivity, and which can be operated in pipe lines nnder high heads. Rapid methods of analysing the observations have been developed, and as a result it has been found possible to design completely battery-operated detection equipment which should give virtually instantaneous measnrement of flow.

The laboratory experiments showed that, subject to certain limitations, the apparatus gave results with 95 per cent confidence limits of error of \pm 1 per cent. The field tests appear to confirm this.
\end{abstract}

\begin{abstract}
Une série complète d'expériences en laboratoire, complétées par des essais industriels, a été effectuée sur le jangeage des debits par la méthode Allen. Des mesures de débit comparatives ont été faites avec une bascule classique de laboratoire et avec des moulinets hydromém triques dans les essais industriels. On a créé un nouvel appareillage, facilement transpor. table dans les campagnes de mesure grace $\dot{a}$ son faible encombrement et à sa légèreté, permettant d'obtenir de bons resultats dans les eaux a hante conductivité initiale, et pouvant s'employer dans les conduites fonctionnant sous une charge élevée. Des méthodes rapides d'analyse des résulfats ont été élaborés; elles ont montré qu'il est possible d'obtenir un appareil. lage de detection alimenté par des piles ćlectriques et devant permettre des mesures de debit pratiquement instantanés.

Dans les expériences en laboratoire, et sons réserve de certaines limitations, l'appareillage a fourni des résultats d'une précision pouvant être chiffrés (avec $95 \%$ de sécurité) $\dot{a} \pm 1 \%$. Les essais industriels paraissent confirmer cette constatation.
\end{abstract}

\section{1. - INTRODUCTION \\ 1. - INTRODUCTION}

The salt velocity method of flow measurement, first described by Allen and Taylor [1], consists essentially of introducing into a stream of liquid a cuantity of another liquid having a different clectrical conductivity; the change in resistance at two pairs of electrodes, spaced a known distance apart in the main stream, is observed as the injected liquid flows past them. By measur-
La méthode de jaugeage des débits par écran salé, présentée en premier lieu par Allen et TayIor [1] consiste essentiellement à injecter dans un liquide en écoulement une certaine quantité d'un deuxième liquide, mais d'une conductivité électrique différente; on observe alors la variation de la résistance sur deux paires d'électrodes disposées à une distance connue l'une ef l'autre 
ing the time taken for the injected liquid to travel between the pairs of electrodes, and the volume of the main stream between them, the now may be obtained.

This report describes work which has been carried out to develop apparatus which would be as flexible and reliable as possible, small and light, and which would produce results of high accuracy which conld be quickly evaluated. The results are given of an extensive series of experiments in a 20-inch diameter pipe-line to determine the accuracy' with which flow measurements could be made, the basis of comparison being simultaneous observations by the saltvelocity method and by means of the laboratory standard weighbridge. Results of a series of ficld measurements in a 40 -inch diameter pipeline where the salt-velocity and current meter methods of measurement were compared are also presented. dans le courant principal, à mesure que le liquide injecté passe au droit de celles-ci. Le débit s'obtient en mesurant le temps mis par le liquide injecté pour traverser la distance entre les deux paires d'électrodes, et en déterminant le volume du courant principal entre les sections qu'elles délimitent.

Le présent rapport décrit les procédés par lesquels on a cherché à mettre au point un appareillage aussi souple et aussi sûr que possible, tout en étant léger et d'un faible encombrement et permettant d'obtenir des résultats très précis et facilement évaluables. Ce mémoire présente les résultats d'une série complète d'expériences réalisées avec une conduite d'un diamètre de $508 \mathrm{~mm}$ et ayant pour objet de déterminer la précision avec laquelle il serait possible de jauger les débits, les comparaisons étant faites sur la base de mesures simultanées par la méthode Allen d'une part, et avec la bascule classique en laboratoire d'autre part. Les résultats d'une série de mesures industrielles dans une conduite de $1,16 \mathrm{~m}$ de diamètre, dans laquelle ont été comparées des mesures par écran salé avec des mesures par moulinet hydrométrique, sont également présentés.

\section{2. - DEVELOPMENT OF APPARATUS AND TECHNIQUE}

\section{2. - MISE AU POINT DES APPAREILS ET DE LA METHODE D'UTILISATION}

This method of flow measurement may be broken down into three operations : injection; detection; and analysis of records. These were con-
Cette méthode de jaugeage peut se décomposer en trois opérations : l'injection, la détection et l'analyse des résultats. Ces trois phases ont

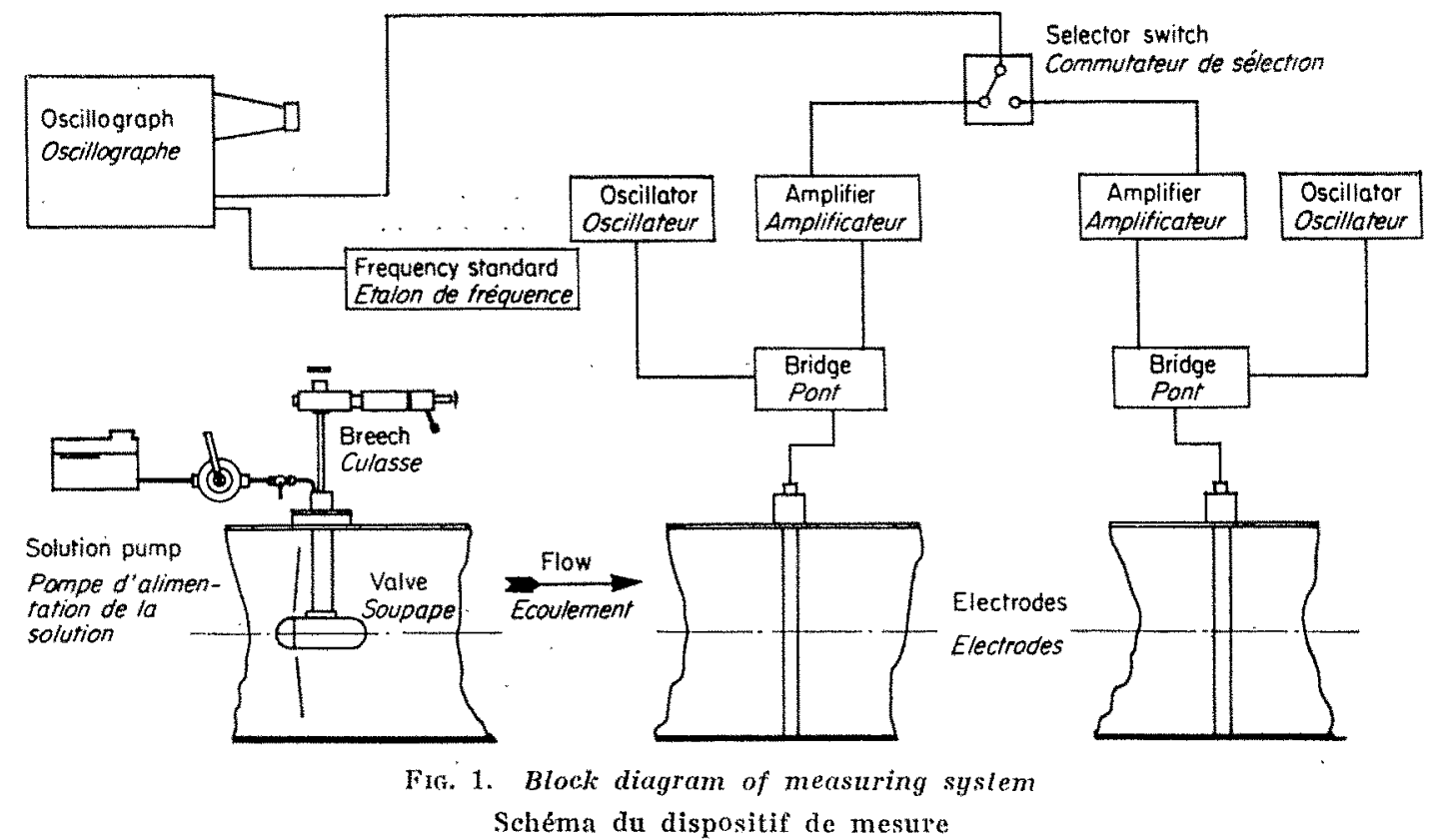




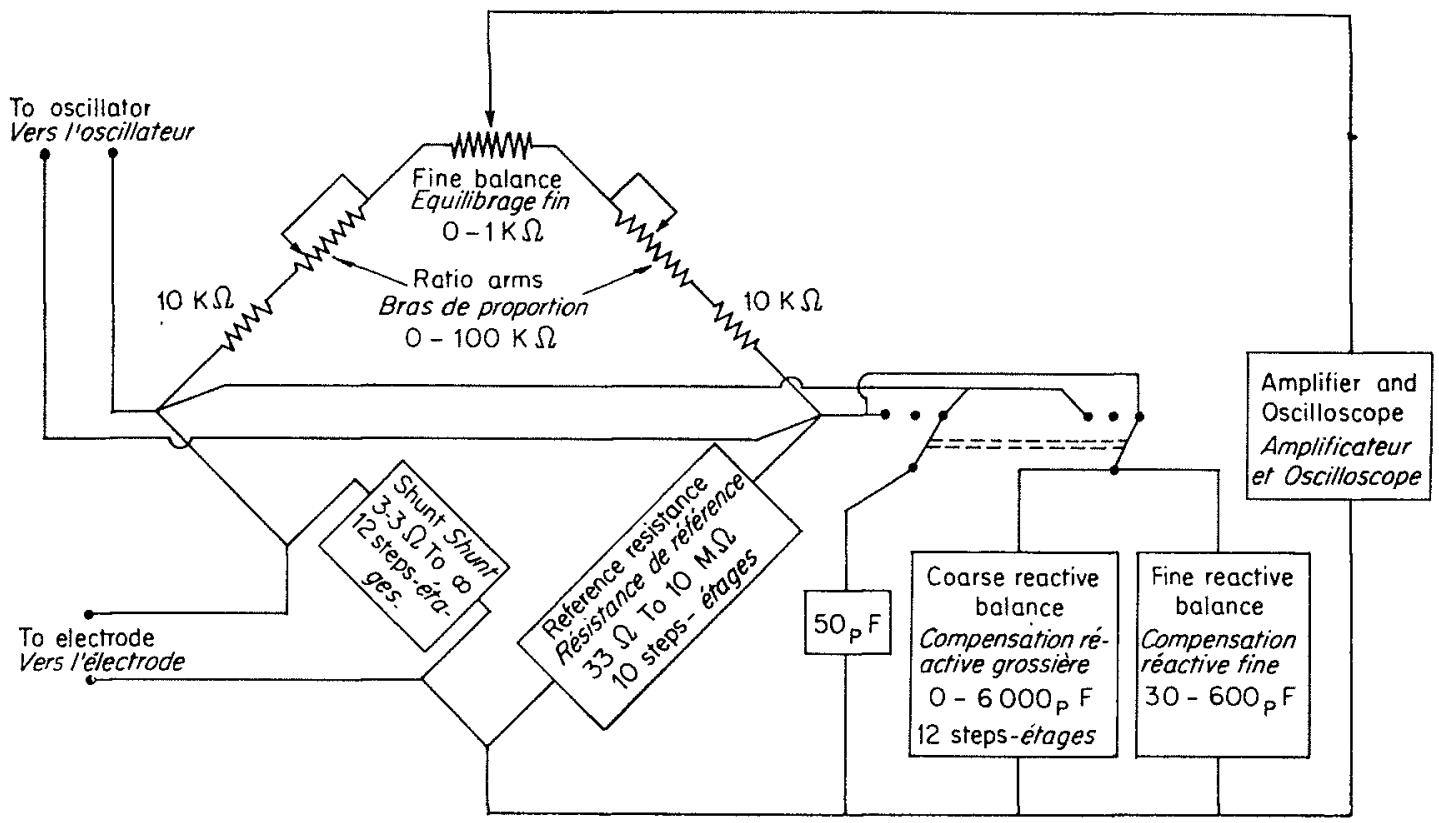

FIfr. 2. Bridge circuit

Circuit du pont

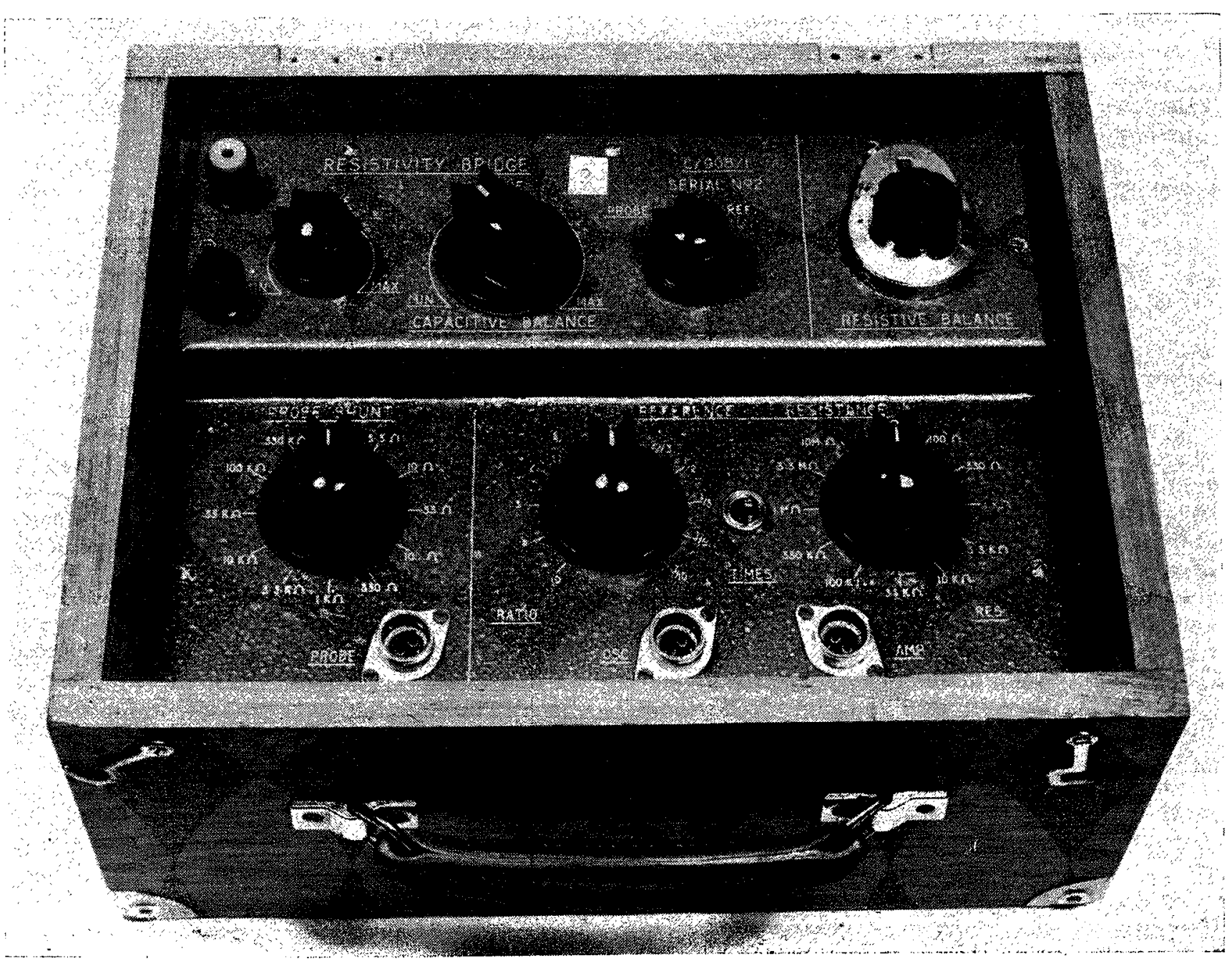

Fic. 3 Resistivity bridge

Pont de résistance 
sidered separately at first, with a view to obtaining optimum performance in each, and then combined for an overall assessment of their behaviour.

\section{1. - Detection of injected solution.}

The first problem considered was that of detecting the presence of the injected solution in the main stream, and the usable range of salt concentrations.

It was decided to employ completely separate a.c.-bridge systems, one for each pair of electrodes. In each bridge, one pair of electrodes formed the aclive arm, the others comprising reference components. With the bridges initially balanced, passage of the injected solution past a pair of electrodes produced an out-of-balance signal which could be amplified and detected in any convenient manner. 'This system appeared to have the following advantages :

High sensitivity.

Zero level independent of conductivity of main stream.

Freedom from polarisation effects.

Frcedom from interference between the two pairs of electrodes.

The bridges were constructed from standard components, and provision was made for balancing out the reactance of the electrodes and the connecting leads as well as the initial resistance. The out-of-balance signals from the bridges were amplified, and applied through a change-over switch to one beam of a double-beam oscillograph. The other beam carried a timing signal from a crystal frequency standard. A block diagram of the installation is shown in Fig. 1, a circuit diagram for the bridges in Fig. 2, while Fig. 3 is a photograph of one of the units. Experiments were made in a 1 -inch diameter pipe, using both point and gauze electrodes, and are fully reported in reference 2 . These showed that it was possible to detect concentrations of common salt of one part in two million, and to obtain a linear response with concentration through the complete chain from electrode to oscillograph. During these tests, short leads were used to connect the electrodes directly to the bridges. In the experiments described in this report, each pair of electrodes was coupled été examinées séparément au début, afin de pouvoir obtenir le meilleur fonctionnement dans chaque cas; elles ont ensuite été combinées pour permettre de juger leur comportement dans l'ensemble.

\section{1. - Détection de la solution injectée.}

Le premier des problèmes examinés était de détecter la présence de la solution injectée dans le courant principal, et de déterminer la gamme de concentrations salines réellement utilisable.

Il a été décidé d'employer des systèmes de ponts à courant alternatif indépendants dont un pour chaque paire d'électrodes. Dans chacun de ces ponts, une paire d'électrodes constituait la branche active, et les autres, les composantes de référence. Les ponts étaient équilibrés au départ, le passage de la solution injectée au droil d'une paire d'électrodes provoquait un signal de déséquilibre se prêtant à l'amplification et à la détection par tout moyen approprié. Les avantages de ce système paraissaient être les suivants:

- Sensibilité élevée;

- Valeur zéro indépendante de la conductivité du courant principal;

- Aucun effet de polarisation;

- Aucune interférence entre les deux paires d'électrodes.

Les ponts ont été fabriqués avec des pièces standards et il a été prévu un moyen de compenser la réactance des électrodes et des câbles de liaison, ainsi que la résistance initiale. Les signaux de déséquilibre provenant des ponts ont été amplifiés et appliqués, par l'intermédiaire d'un commutateur, à l'un des faisceaux d'un oscillographe à double faisceau. L'autre faisceau portait un signal de temps émis par un cristalétalon de fréquence. L'installation est montrée sous forme schématique par la figure 1, ainsi qu'un schéma des circuits des ponts par la figure 2, et par photographie d'un des appareils dans la figure 3 . Des essais ont été effectués dans un tuyau de $25,4 \mathrm{~mm}$ de diamètre en employant des électrodes ponctuelles et des électrodes à grille; ces essais sont présentés en détail dans la référence [2]. Ils ont montré qu'il était possible de détecter des concentrations de sel ordinaire de $1 / 2.10^{\circ}$ et d'obtenir une réponse linéaire en fonction de la concentration, sur toute la chaîne, de l'électrode à l'oscillographe. Des câbles courts ont été utilisés pendant ces essais pour relier les électrodes directement aux ponts. Dans les essais décrits dans ce mémoire. chaque paire d'électrodes était reliée au pont par $91,5 \mathrm{~m}$ de câble blindé haute fréquence et il s'est révélé nécessajre d'établir la connexion par l'intermédiaire de transformateurs adaptés aux oscillations du pont. 
to the bridge by 100 yards of R.F. screened cable, and it was then found necessary to connect them through matching transformers to suit the bridge oscillators.

For the experiments of reference [2] and the laboratory tests described in this report, two commercial mains-operated bridge oscillators and amplifiers were used, operating at frequencies of 1000 and 1500 cycles per second respectively. These performed quite satisfactorily, but for field tests it was felt that battery-operated equipment offered greater flexibility. While the laboratory experiments were in progress, work had been carried out by the Instrument Group to develop transistor-oscillators and amplifiers suitable for this purpose, together with a transistor crystal frequency standard.

These units (which operated at a frequency of 10 kilocycles per second) were tested in the laboratory installation, and shown to give results as satisfactory as those obtained from the mains-operated apparatus. It was decided to use them during the field tests in order to assess their performance under practical working conditions. They have been fully described by Leslie and Hunter [3].

So far as the electrodes themselves were concerned, the experiments of reference [2] suggested that point measurements were unreliable. Consistent results had been obtained with gauze electrodes spanning the whole pipe section, but this system was obviously impractical for fullscale use. It was felt that the design should be such that the electrodes were robust, offered minimum resistance and obstruction to flow, spanned at least one pipe diameter and could be installed from outside the pipe without internal rigging or support. The design adopted provided two conducting strips inlaid in a 'Perspex' rod which formed the leading edge of a streamlinesection strut. Its length was sufficient to span the diameter of the pipe, and it could be inserted through a 2 -inch diameter hole in a screwed boss attached to the outside of the pipe. A pad of rubber at the lower end rested on the pipe wall, and sufficient compression was applied by the screw of the boss to ensure a stable assembly. Leads form each of the conducting strips were taken through the strut to a two-pin waterproof plug outside the pipe. The strips themselves were chromium plated to reduce changes in resistance due to surface contamination. Electrodes were constructed to suit the 20-inch diameter laboratory pipe-line and the 40 -inch diameter line used in the field trials.
Dans les expériences décrites dans la référence [2] et les essais en laboratoire relatés dans le présent rapport, on employa deux oscillateurs de pont et amplificateurs alimentés à partir du courant du secteur, fonctionnant respectivement à des fréquences de 1000 et 1500 périodes par seconde. Ces appareils ont bien lonctionné, mais dans les essais industriels, il a été considéré que les appareils alimentés par des accumulateurs présentaient plus de souplesse. Alors que les expériences en laboratoire étaient en cours, l' «Instrument Group 》(Service «Appareils ») avait mis au point des oscillateurs el des amplificateurs à transistors répondant à ces besoins, ainsi qu'un cristal-étalon de fréquence, à transistor.

Ces appareils, qui fonctionnaient à la fréquence de $10 \mathrm{kc} / \mathrm{s}$, ont été vérifiés sur l'installation du laboratoire; les résultats obtenus étaient aussi bons que ceux obtenus avec les appareils alimentés à partic du secteur. Il a donc été décidé d'employer les appareils à batterie pour les essais industriels, atin de pouvoir juger leur comportement dans des conditions de fonctionnement pratiques. Leslie et Hunter 53 ] en ont fourni une description complète.

En ce qui conccrne les électrodes proprement dites, les expériences décrites dans la référence [2] ont indiqué que des mesures ponctuelles étaient peu sûres. O'n avait, par contre, obtenu des résultats qui se tenaient, avec des électrodes en treillis, à travers toute la section de la conduite, mais cette disposition ne pouvait évidemment convenir pour une utilisation pratique à l'échelle grandeur nature. L'appareillage devait comporter des électrodes robustes, présentani les plus faibles résistance et obstruction possibles à l'écoulement, portant sur au moins un diamètre de la conduite, et pouvant être installées à l'extérieur sans nécessiter de haubanage ou de supports internes quelconques. La disposition adoptée comportait deux bandes conductrices incrustées dans une tige de plexiglas, constituant le bord avant d'une perche de section pisciforme. La longueur de cette perche était suffisante pour lui permeltre de franchir le diamètre de la conduite, en l'introduisant par un trou de $50 \mathrm{~mm}$ de diamètre pratiqué dans un bossage fileté monté sur l'extérieur de la conduite. L'extrémité inférieure comportait un tampon en caoutchouc, qui portait contre la paroi de la conduite; en le comprimant suffisamment au moyen d'une vis prévue dans le bossage, on assurait un ensemble stable. Des câbles attachés aux deux bandes conductrices passaient à l'intérieur de la perche, leurs extrémités étant re. liées à une fiche bipolaire étanche à l'extérieur. de la conduite. Les bandes conductrices etaient chromées afin de limiter les variations de ré- 


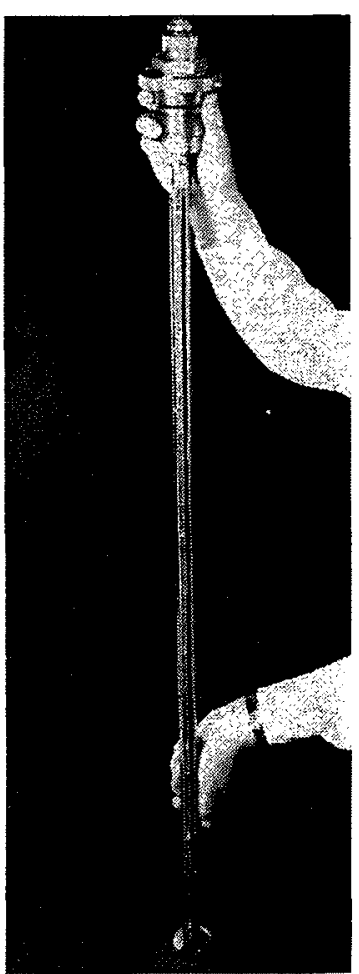

Fig. $4 a$.

40-inch electrode

Electrode de 1 mètre
Fig. $4 b$

Details of conducting strips Détail des bandes conductrices

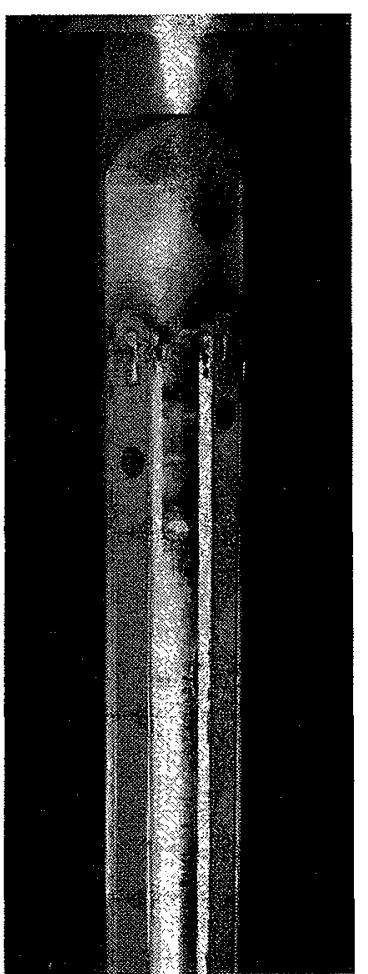

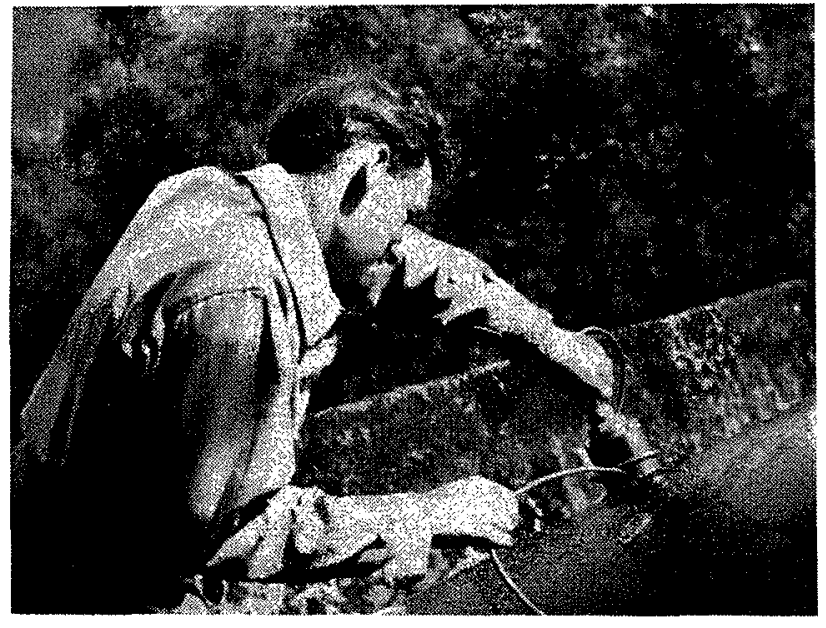

Fig. 4 shows a full view of one of the 40 -inch electrodes, a detail of the conducting strips, and a view of the boss and plug outside the pipeline.

\section{2. - Injection apparatus.}

The development of sensitive detecting apparatus meant that it would be possible to use small quantities of injected solution and, in
Fia. $+c$. Fxternal connection to electrode mounted in pipe-line

Raccordement extérieur à l'électrode placée dans la conduite

sistance dues à la contamination de leurs surfaces. Des électrodes ont été réalisées pour la conduite de $508 \mathrm{~mm}$ du laboratoire, et pour celle de $1,16 \mathrm{~m}$ des essais industriels.

La figure 4 montre une des électrodes de $1,16 \mathrm{~m}$, un détail des bandes conductrices, et une vue du bossage et du bouchon montés sur la paroi extérieure de la conduite.

\section{2. - Dispositif d'injection.}

La mise au point d'un appareillage de déteclion à haute sensibilité signifiait qu'il ćtait possible d'injecter de faibles volumes de solution. 
designing the injection device, full advantage was taken of this fact. It was known that field tests of a complete system could be carried out on a 40-inch diameter pipe-line, and, as a first objective, it was decided to attempt to produce an injector capable of delivering salt solution over the full area of this pipe. Preliminary calculations, based on experience with the 1-inch diameter-pipe, suggested that a volume of 2 to 3 cubic inches of saturated common salt solution delivered in 100 milliseconds into the 40-inch pipe would produce satisfactory records at electrode stations spaced up to 50 pipe diameters downstream of the injection point. The area to be covered, and the need for comparatively rapid injection if small quantities of solution were to be employed, meant that high injection pressures would be needed. After considering a number of possibilities, it was finally decided that the scheme offering the greatest advantage was one in which a power cartridge could be used to provide the pressure needed for injection.

The final design of injection valve is shown diagrammatically in Fig. 5. Referring to the notation on this diagram, the operation is as follows :

Salt solution is contained in chamber 5 , con-

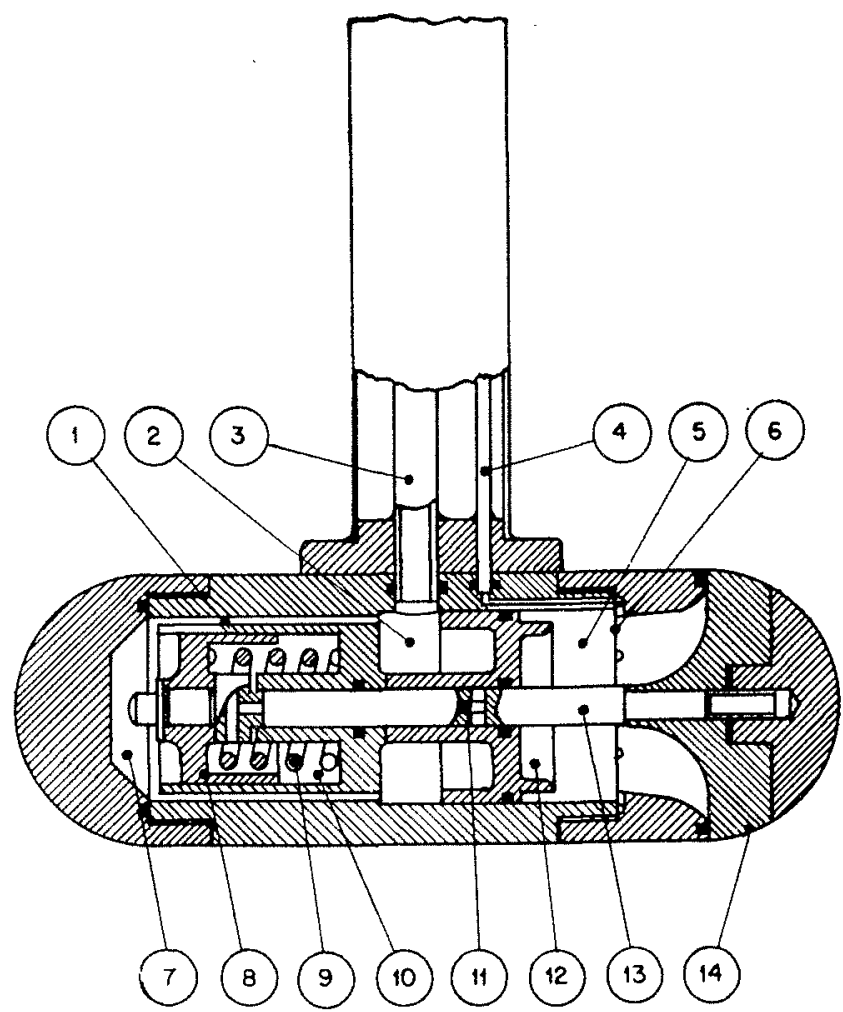

Cette possibilité a été exploitée au maximum dans l'étude du dispositif d'injection. On savait qu'il était possible d'cffectuer des essais, à l'échelle industrielle, d'un système complet, sur une conduite de $1,16 \mathrm{~m}$, et il a donc été décidé, conme premier objectif, de réaliser un injecteur pouvant introduire une solution saline sur toute la section d'une telle conduite. Les calculs préliminaires, basés sur les expériences réalisées avec la conduite de $25,4 \mathrm{~mm}$ de diamètre, ont suggéré qu'un volume de 32 à $49 \mathrm{~cm}^{3}$ d'une solution saturée de sel ordinaire injectée en 100 millisecondes dans la conduite de $1,16 \mathrm{~m}$ permettrait d'enregistrer des résultats convenables avec des électrodes implantées à des intervalles allant jusqu'à cinquante fois le diamètre de la conduite à l'aval du point d'injection. Etant donné la surface à explorer, et la nécessité de pouvoir effectuer les injections assez rapidement, si l'on envisageait d'employer de faibles volumes de soIution, il était essentiel que les pressions d'injection soient élevées. Après avoir examiné plusieurs possibilités, il a finalement été décidé qu'un dispositif dans lequel une cartouche détonante fournirait la pression d'injection voulue, présentait le plus d'intérêt.

La disposition finalement adoptée pour la soupape d'injection est montrée schématiquement par la figure 5 . Suivant les notations de ce schéma, le fonctionnement du dispositif est le suivant :

La solution saline est emmagasinée dans la

Fig. 5. Injection valve

Soupape d'injection

1. Connecting pipe

Passage de liaison

2. Pressure chamber

Chambre à pression

3. Pressure transmitting pipe

Tube de transmission de pression

4. Solution connecting pipe

Tube vers la pompe à solution

5. Solution chamber

Chambre à solution saline

6. Ejector piston limit stop Butée du piston d'éjection

7. Valve pressure chamber Chambre de pression de la soupape

8. Valve operating piston Piston de commande de la soupape

9. Recuperating spring Ressort de rappel

10. Recuperating spring chamber Logement du ressort de rappel

11. Transfer ports Lumières de transfert

12. Ejector piston Piston d'éjection

13. Valve spindle

Tige de soupape

14. Value Soupape 

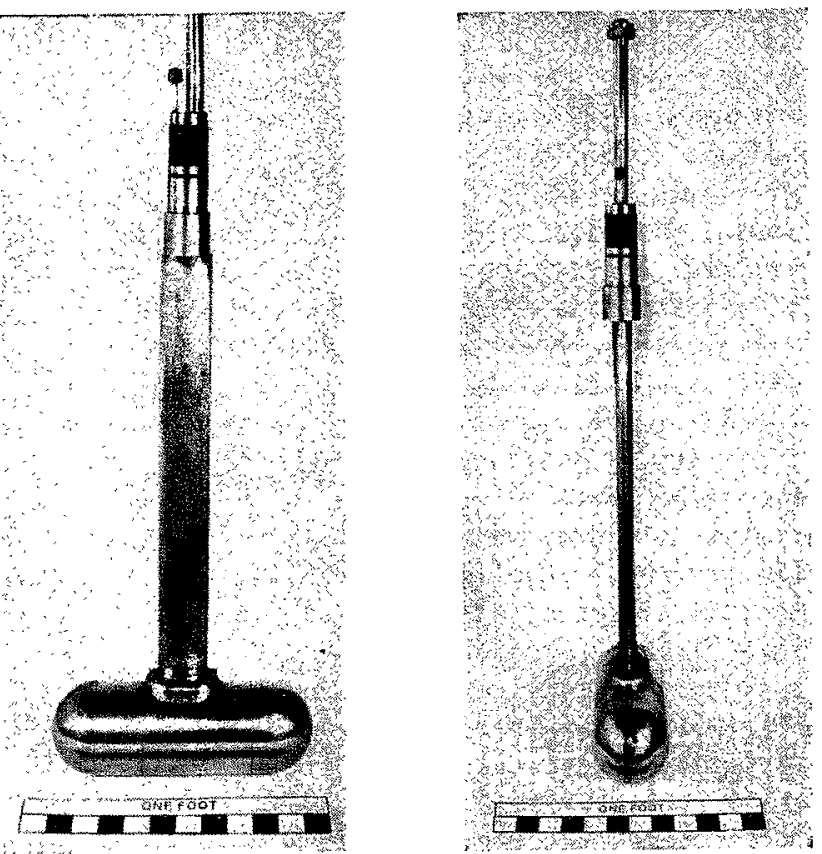

Fig. 6 a. Injection valve Soupape d'injection

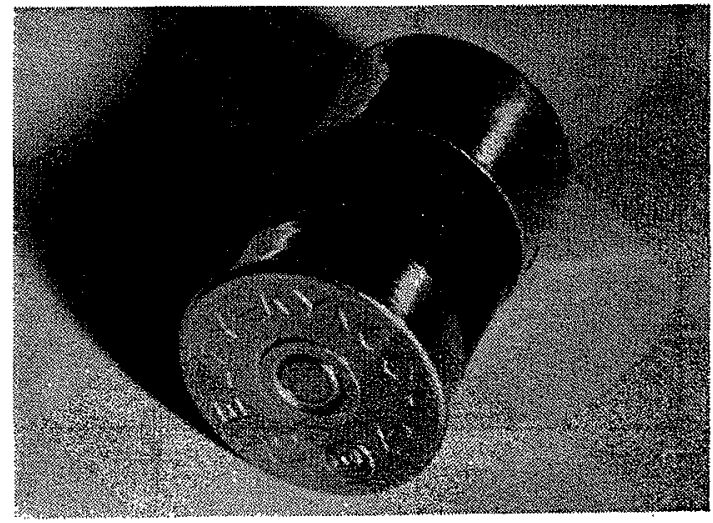

Fia. 6 b. Cartidge Cartouche

nections 3 and 4 being carried through the mounting strut to a breech and a solution punp respectively. Detonation of a cartridge in the breech produces a volume of high-pressure gas which passes through connection 3 to chamber 2 and thence through passages 1 to chamber 7 . The pressure operates on piston 8 to open valve 14 and on piston 12 to drive solution out of chamber 5 . Shortly before the end of its travel (which is limited by stop 6) piston 12 uncovers ports in the spindle 13, allowing gas to flow through passage 11 to chamber 10 thus equalising the pressure on both sides of piston 8 . Spring 9 then acts to return the valve to its seat with a Poree of some 400 pounds. Fresh solution is pumped into the chamber via connection 4 , forc-

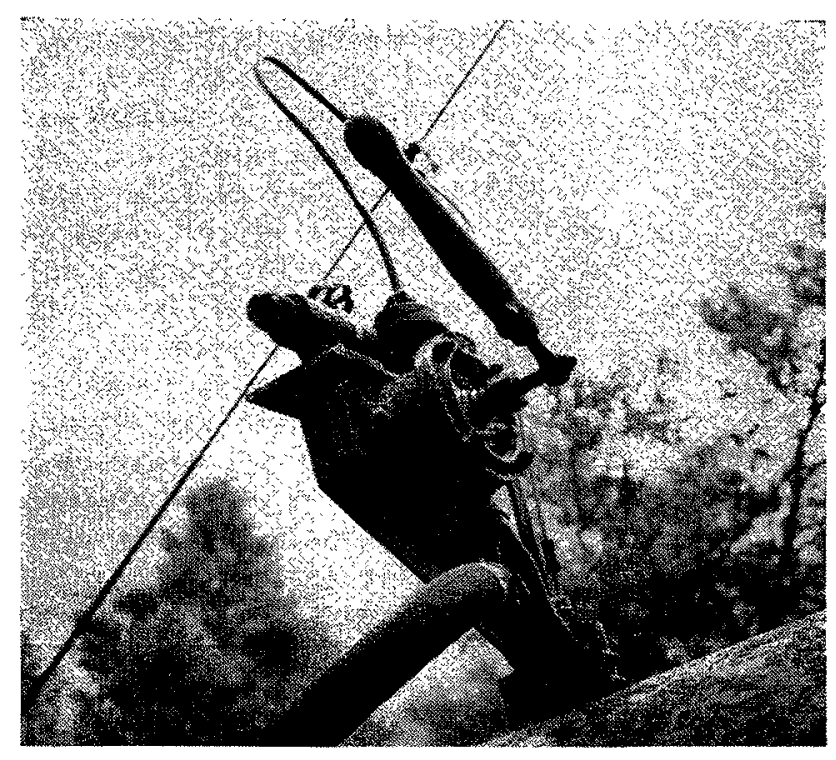

Fia. 7 . Breech assembled on pipe-line Culasse montée sur la conduite

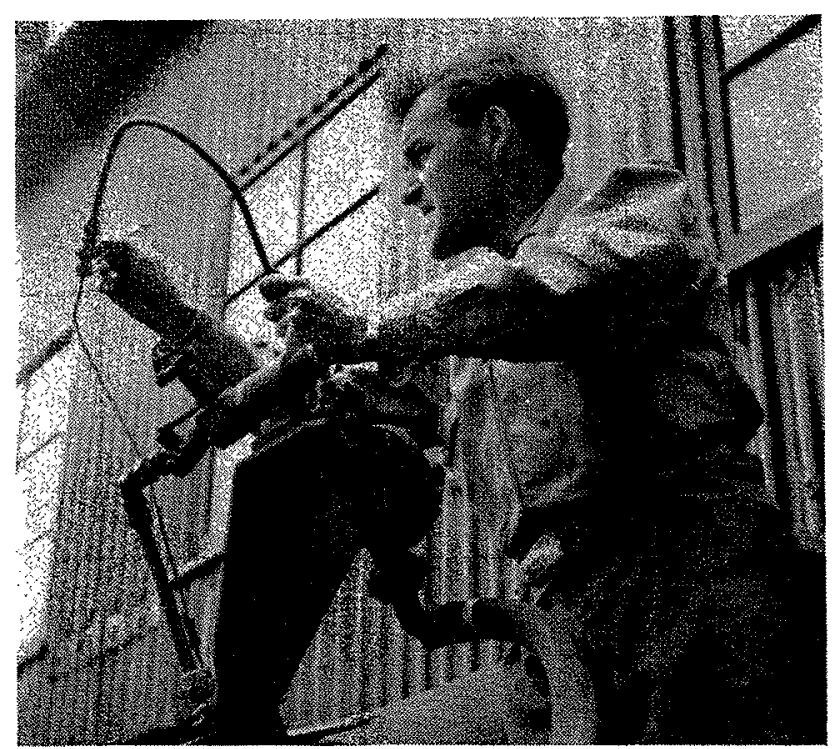

chambre (5), les deux tubes (3) et (4) passant à l'intérieur de la perche, le tube (3) élant relic à une culasse, et le tube (4) à une pompe de solution. En explosant dans la culasse, la cartouche produit un volume de gaz a haute pression, qui se rend par le tuyau (3) dans la chambre (2) et de là par les passages (1) dans la chambre (7). La pression agit sur le piston (8), provoquant l'ouverture de la soupape (14), ainsi que sur le piston (12), qui chasse la solution de la chambre (5).

Peu avant d'atteindre la fin de la course [celleci étant limitée par la butée (6)], le piston (12) démasque des ouvertures pratiquées dans l'axe (13), permetlant aux gaz de pénétrer par le passage (11) dans la chambre (10), en egalisant ainsi 
ing piston 12 back to its starting position, ready for the next cycle of operations.

A cock to release the gas pressure in the valve is provided adjacent to the breech, and there is an isolating cock between the valve and the solution pump. A bursting disc in the breech assembly prevents damage by excess pressure in the case of a fault in operation. Fig. 6 shows the injection valve as actually used in the experiments, together with a 12-bore cartridge, and Fig. 7 the breech assembly installed on the pipeline used for field tests.

When a prototype valve had been made to this design, a series of experiments was carried out in conjunction with the cartridge manufacturer to determine its performance, and the most suitable composition for the cartridge charge. For these tests, the valve was suspended opposite an observation window in the laboratory sump. 'The salt solution used was coloured with red dye for visual observation, and a pair of search electrodes which could be set at known radial distances from the valve outlet were used for electrical observation. Records where taken on a three-channel oscillograph of the pressure in the breech and the change in resistance at the search electrodes against a time base.

It was found that reliable discharge to a radius of 20 inches could be obtained using cartridges which developped a pressure of 3000 pounds per square inch in 1 millisecond after detonation. The time taken from appearance of solution just outside the valve outlet to its appearance at the 20 -inch radius was approximately 50 milliseconds. Sufficient trials were made to establish that the results were repeatable, and that contamination of the valve with combustion products from the cartridges did not interfere with the operation of the valve for at least 100 cycles.

The cartridges were detonated by percussion cap in a manually-operated breech. It had originally been hoped to use a multiple-breech with electrically detonated cartridges, but difficulties were encountered in developing these. The manufacturers are hopeful that the problems can be satisfactorily solved, so that the extra flexibility of operation offered by multiplie loading and remote firing can be obtained. les pressions de part et d'autre du piston (8). Le ressort (9) agit alors en plaquant la soupape sur son siège avec une force de l'ordre de $180 \mathrm{~kg}$. Enfin, une nouvelle charge de solution est pompée dans la chambre, par l'intermédiaire du tuyau (4), ramenant le piston (12) à sa position de départ, et préparant le dispositif pour son prochain cycle de fonctionnement.

Un robinet permettant de détendre la pression des gaz dans la soupape est prévu à côté de la culasse, ainsi qu'un robinet d'isolement entre la soupape et la pompe à solution. Une pastille de sécurité est prévue sur la culasse afin d'éviter l'endommagement du dispositif par une surpression dans le cas d'un défaut de fonctionnement. Le figure 6 montre la soupape d'injection employée pour les essais, ainsi qu'une cartouche du calibre 12 de chasse et la figure 7 montre la culasse installée sur la conduite servant aux essais industriels.

Après la réalisation d'une soupape prototype suivant cette disposition, il a été effectué une série d'essais en collaboration avec le fabricant de cartouches, ayant pour objet de vérifier le fonctionnement du dispositif et de déterminer le chargement optimal de la cartouche. Pour ces essais, la soupape était suspendue en f'ace d'un hublot d'observation dans le bassin du laboratoire. Un colorant rouge a été ajouté à la solution saline, afin de faciliter la visualisation des phénomènes, et une paire de sondes pouvant être implantées à des distances radiales connues de la sortie de la soupape a été prévue pour les mesures électriques. La pression dans la culasse et les variations de résistance aux électrodes de sondage ont été enregistrées par un oscillographe à trois voies en fonction d'une base de temps.

On a constaté qu'il était possible de réaliser des débits d'injection sûrs jusqu'à un rayon de $508 \mathrm{~mm}$ en employant des cartouches pouvant fournir une pression de $205 \mathrm{~kg} / \mathrm{cm}^{2}$ une milliseconde après la détonation de la charge. Le temps écoulé entre l'apparition de la solution juste à la sortie de la soupape et le moment ou elle atteignait l'extrémité du rayon de $508 \mathrm{~mm}$ était d'environ 50 millisecondes. Un nombre suffisant d'essais a été effectué pour s'assurer que les résultats étaient toujours reproductibles, et que la détérioration de la soupape par les produits de combustion des cartouches ne gênerait pas le fonctionnement de la soupape pendant au moins 100 cycles.

La détonation des cartouches était provoquée par la percussion de l'amorce dans la culasso commandée à la main. On avait d'abord espéré pouvoir utiliser une culasse multiple à détonation électrique, mais sa mise au point s'est heurtée à certaines difficultés. Toutefois, les fabricants ont bon espoir de résoudre ces problèmes, afin d'obtenir une parfaite souplesse de fonc- 


\section{3. - Evaluation of results.}

The turbulence of the main stream flowing in a pipe or channel causes fairly rapid diffusion of any solution injected into it, a process which has been studied theoretically and experimentally by Taylor [4]. After injection there is thus a finite length of stream travelling with the flow in which the electrical conductivity is different from that of the main stream, and this length increases with distance from the point of injection. (According to Taylor it is proportional to the square root of the distance from the injection point.)

A characteristic form of oscillograph record is obtained from the two pairs of electrodes, as shown in Fig. 8, which gives prints of typical records. It will be seen that these are similar to the records obtained in the 1-inch pipe experiments of reference [2].

Since, due to the turbulent diffusion, the two traces are not identical, it is necessary in order to determine the time of passage between the two electrode stations to choose a characteristic point on the traces which can be considered to travel with the mean velocity of flow. Reference [4] suggests on theoretical and experimental grounds that this point should be the peak of each trace. However, the results quoted therein were obtained for special conditions of injection, and for very long spacings between injection point and electrode stations, neither of which can applied on a practical scale. Furthermore, with the type of record usually obtained in fullscale testing it is difficult to determine the posilion of the peaks of the traces with any great precision.

It has been usual practice in the application of the salt-velocity method to choose the centres of area of the two traces as the characteristic points, and the experiments described in reference [2] showed that this gave more consistent results than using the peak points. Various methods are available for determining the positions of the centres of area, but as the oscillograph records were obtained on 35-millimetre film, it was found convenient to project them in a photographic enlarger to obtain measurements for a process of numerical integration. The use of Simpson's rule, which had been previously employed, gave satisfactory results, but was exceedingly tedious since a large number of or- tionnement, au moyen de plusieurs cartouches détonant par commande à distance.

\section{3. - Appréciation des résultats.}

La turbulence du courant principal dans une conduite on un canal provoque la diffusion assez rapide de toute solution qui y est injectée; ce phénomène a fait l'objet d'études théoriques et expérimentales de la part de Taylor [4]. Il y a donc, après l'injection, une longueur finie du courant qui se déplace avec l'écoulement, et dans laquelle la conductivité électrique diffère de celle du courant principal; cette longueur augmente avec l'éloignement du point d'injection (d'après Taylor, elle est proportionnelle à la racine carrée de l'éloignement du point d'injection).

L'enregistrement provoqué sur l'oscillographe par les deux paires d'électrodes a une forme caractéristique, comme le montre la figure 8 , qui représente des enregistrements typiques. Notons la ressemblance entre ces formes et celles obtenues dans les essais en conduite de $25,4 \mathrm{~mm}$ faisant l'objet de la référence [2].

Puisque les deux tracés ne sont pas identiques (en raison de la diffusion turbulente), il est nécessaire, pour dèterminer la durée de passage entre les deux paires d'électrodes, de choisir sur les tracés un point caractéristique quelconque que l'on peut supposer se déplaçant à la vitesse moyenne de l'écoulement. La référence [4] suggère, pour des raisons théoriques et expérimentales, que ce point devrait être situé sur la crête de chaque tracé. Toutefois, les résultats mentionnés dans cette référence étaient obtenus pour des conditions d'injection spéciales, et avec des distances considérables entre le point d'injection et les électrodes, conditions et distances ne convenant guère à des utilisations pratiques. De plus, avec le genre d'enregistrement que l'on obtient normalement dans les essais à l'échelle grandeur nature, il est difficile de déterminer la position des crêtes des tracés avec une bonne précision.

Dans la méthode de jaugeage par ćcran salé, on choisit couramment les centres de surface de deux tracés comme points caractéristiques; les expériences décrites dans la référence [2] ont d'ailleurs montré que les résultats étaient plus fidèles que si l'on avait procédé d'une autre manière. Il existe plusieurs méthodes pour déterminer les positions des centres de surface, mais comme l'enregistrement des tracés de l'oscillographe était fait sur un film de $35 \mathrm{~mm}$, on a trouvé commode de les projeter dans un agrandissement photographique pour obtenir des mesures permettant une intégration numérique. L'emploi de la règle de Simpson, méthode déjà utilisée auparavant, a fourni de bons ré- 


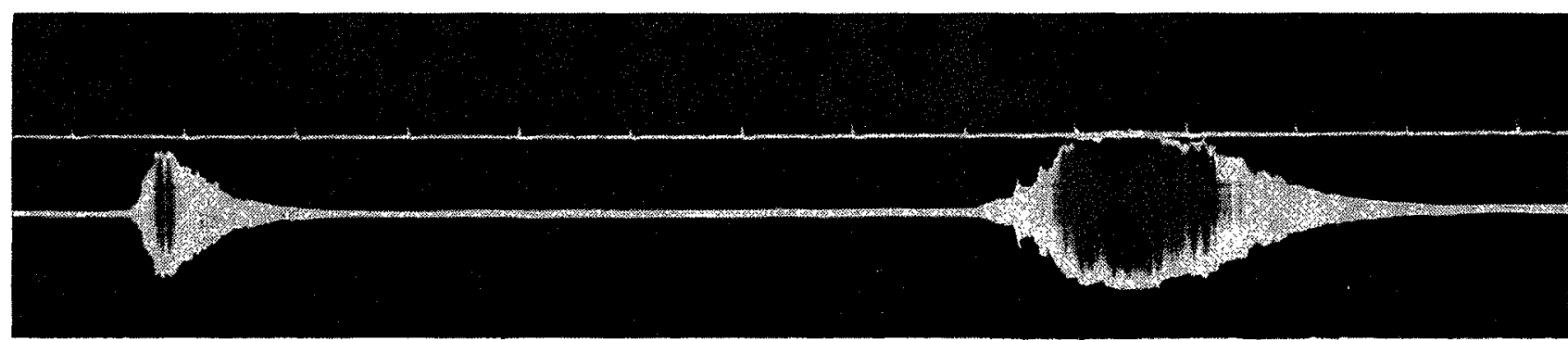

20-inch pipe:line. Flow 18 cubic feet per second (approx.) Conduite de $508 \mathrm{~mm}$. Débit $510 \mathrm{l} / \mathrm{s}$ (environ)

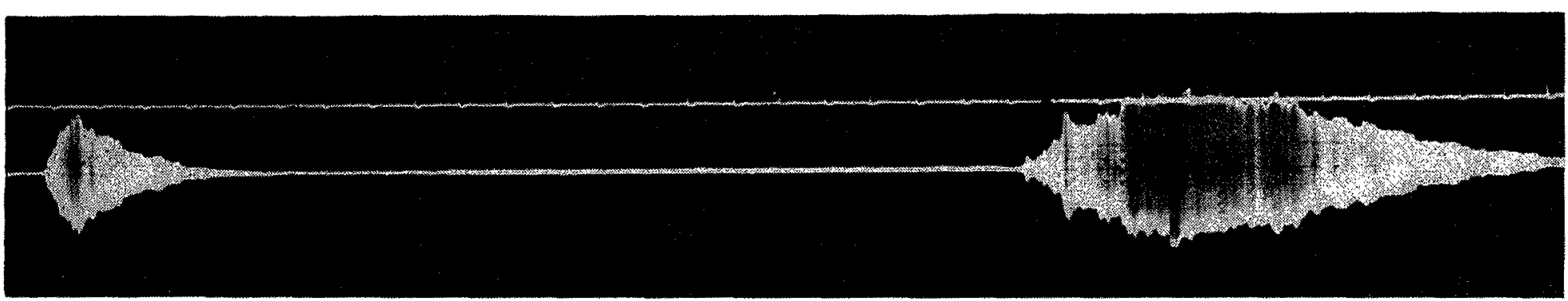

20-inch pipe-line. Flow 4.5 cubic feet per second (approx.)

Conduite de $508 \mathrm{~mm}$. Débit $1271 / \mathrm{s}$ (environ)

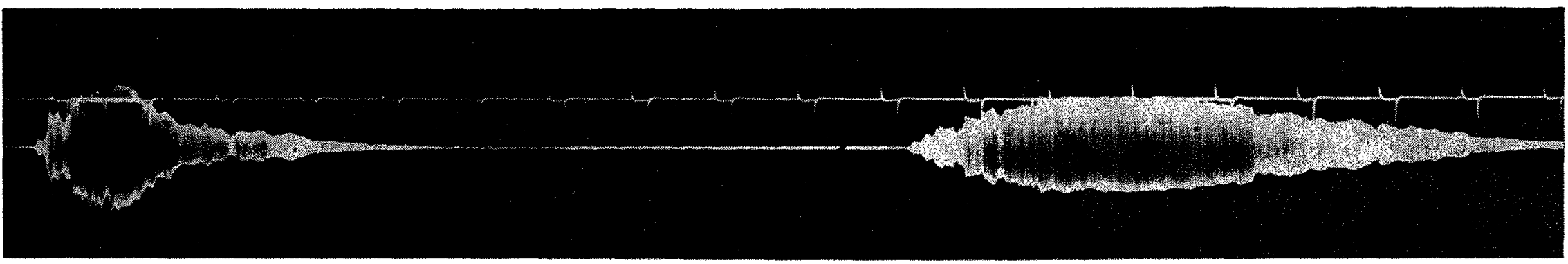

40-inch pipe-line (field tests). Flow 60 cubic feet per second (approx.) 
dinates had to be measured. It was therefore decided to try other methods, the most attractive of which was Lobatto's five-ordinate rule. This required only three actual measurements, since two of the five ordinates needed were at the beginning and end of the trace and had zero value. The process is illustrated diagrammatically in Fig. 9. By preparing suitable chart scales on whith the necessary spacing of the five ordinates was marked, and adjusting the degree of enlargement so that the projection of a trace exactly fitted between the end ordinates sultats, mais elle s'est montrée fastidieuse, étant donné le grand nombre d'ordonnées qu'il fallait mesurer. Il a done été décidé d'essayer d'autres méthodes, parmi lesquelles la règle des cinq ordonnées de Lobato présentait le plus d'intérêt. Avec celle-ci, trois mesures seulement suffisaient, car deux des cinq ordonnées requises étaient situées au début et à la fin du tracè, ayant ainsi la valeur zéro. Le procédé est représenté schématiquement par la figure 9. Les mesures requises pouvaient être faites aisément en préparant des échelles de diagramme conve-

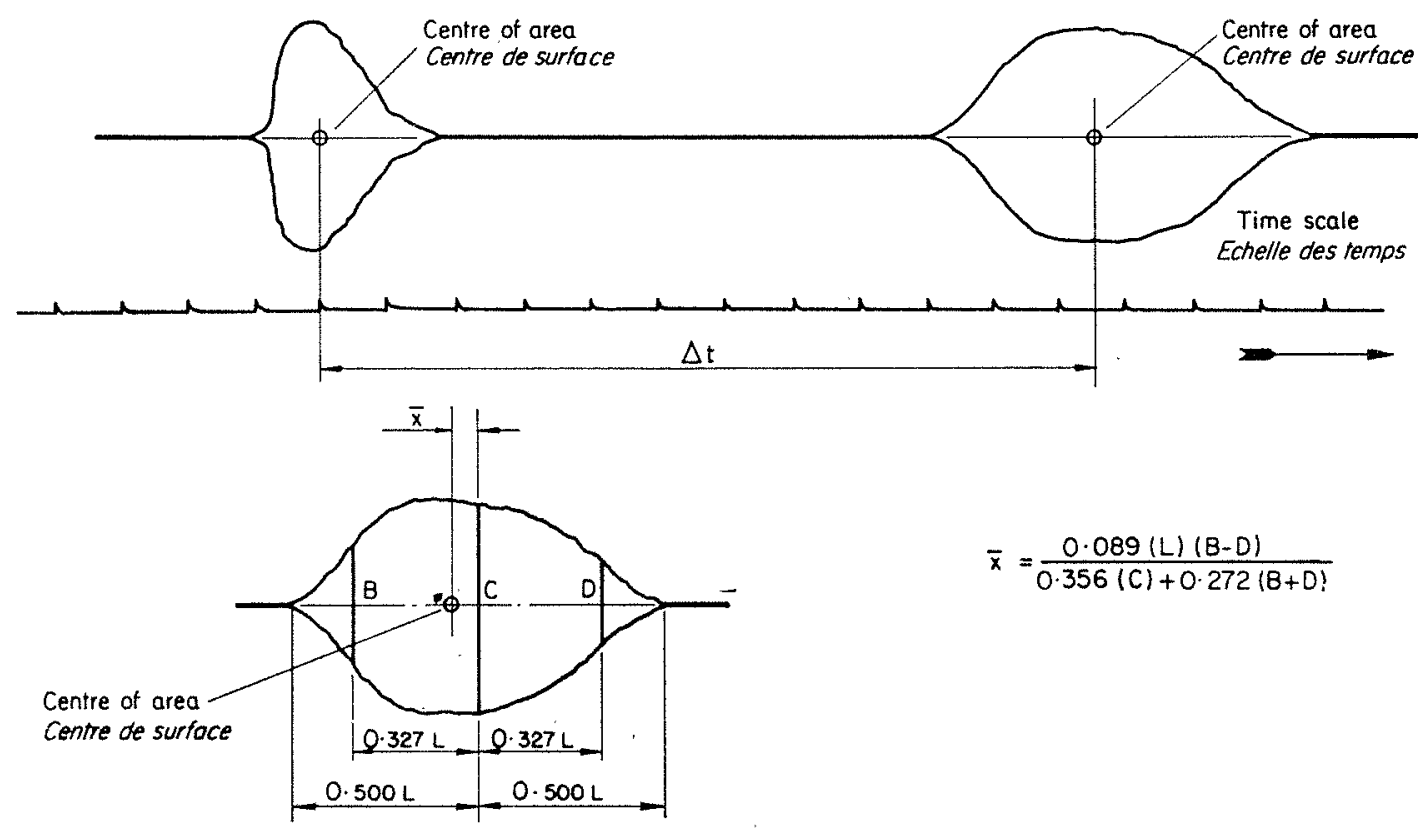

Fia. 9. Time of passage by centres of arca

Temps de passage par la méthode des centres de surface

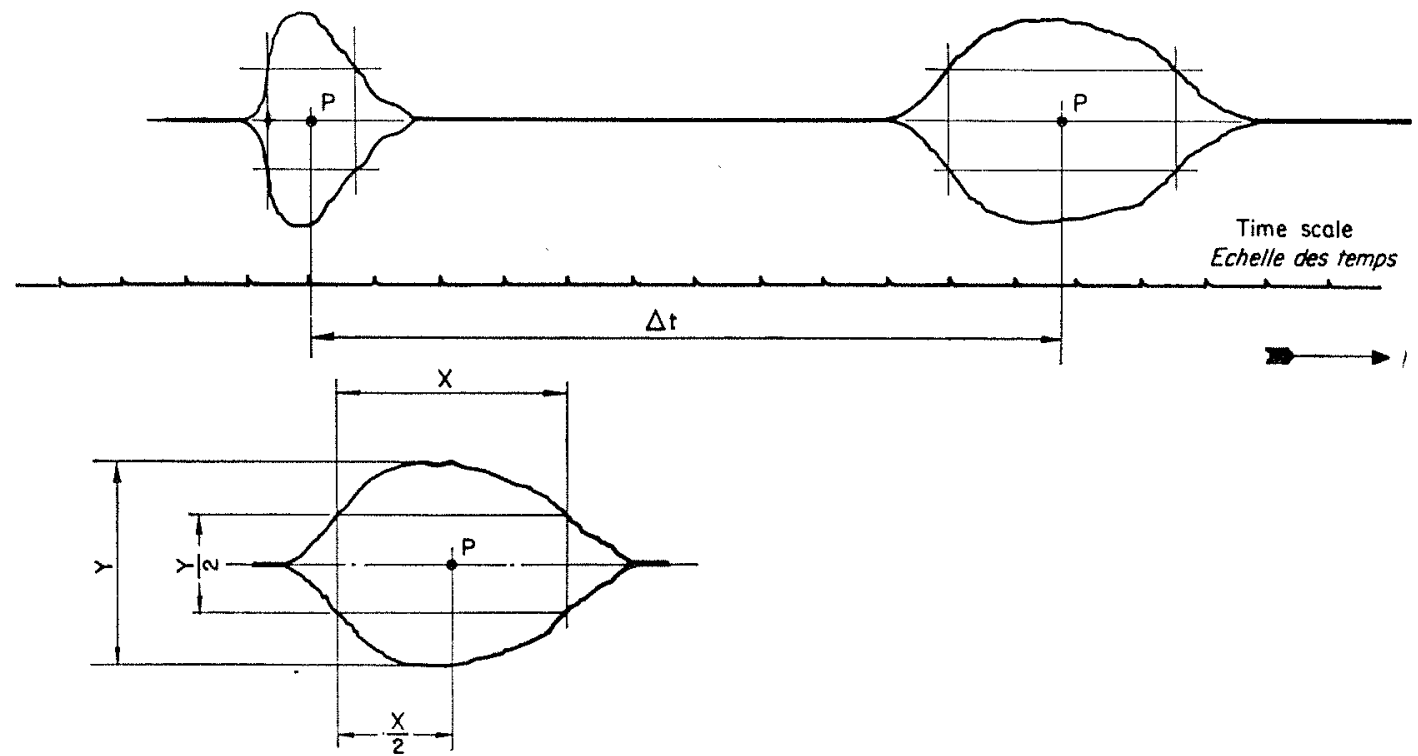

FIG. 10. Time of passage by simplified method

Temps de passage déterminés par la méthode simplifiée 
of a chart, the required measurements could be made easily. The results of using Lobatto's rule were compared with those using Simpson's rule on the same sets of records, and both methods were found to agree within the limits of accuracy of measurement. Lobatto's rule was therefore used throughout the experiments.

Though a considerable saving in time and trouble had been made, the use of a characteristic point more easily found than the centre of area offered further possibilities of improvenent. A systematic investigation of the geometry of the records revealed that results as accurate and consistent as those based on the centres of area of the traces could be obtained by using the midpoints of horizontal lines joining the points on the traces where the ordinates were half the peak ordinates. This process is illustrated diagrammatically in Fig. 10. The necessary measurements were made by projecting the records as before, and the time taken for measurement and calculation was substantially reduced.

During the course of the experiments the records were evaluated both by taking centres of area calculated from Lobatto's rule and by the "midpoint of half-maximum ordinate" method. The results of both are presented in the relevant tables. nables, en y repérant l'intervalle nécessaire des ving ordonnées, et en choisissant un grossissement tel que la projection d'un tracé s'ajustât exactement entre les ordonnées extrèmes d'un diagramme. Les résultats obtenus avec la règle de Lobatto ont été comparés avec ceux ohtenus avec la règle de Simpson, sur les mêmes grompes d'enregistrements, et il s'est avéré que les deux méthodes s'accordaient dans les limites de la précision de mesure habituelle. Le choix s'est done porté sur la règle de Lobatto pour l'ensemble des essais.

Bien que cette méthode ait deja permis une économie considérable de temps et de peine, il a été possible de la perfectionner encore en utililisant un point caractéristique plus facile à déterminer que le centre de surface.

Un examen systématique de la géométrie des enregistrements a révélé la possibilité d'obtenir des résultats aussi précis ef fidèles qu'avec la méthode des centres de surface si l'on employait les points médians des lignes horizontales reliant les points des tracés dont les ordonnées étaient égales à la moitié des ordonnées des crêtes (fig. 10). Les mesures nécessaires ont été faites en projetant les enregistrements, comme dans le cas précédent, et le temps exigé pour les mesures et les calculs s'en est trouvé considérablement réduit.

Les enregistrements obtenus pendant les expériences ont été appréciés tant à partir des centres de surface calculés d'après la règle de Lobatto, que par la méthode «du point médian de l'ordonnée égale à la moitié de l'ordonnée maximale $»$. Les résultats obtenus par les deux méthodes sont présentés dans les tableaux correspondants.

\section{3. - LABORATORY TESTS}

\section{3. - ESSAIS EN LABORATOIRE}

The laboratory experiments were conducted in a 20-inch diameter pipe-line having a total length of 700 feet arranged in two 350 -foot legs. This line was supplied from a constant head tank by means of which the pressure across it conld be maintained at 38 feet of water $\pm 1 / 8$ inch. The Now discharged through a control valve and diverting gear either into a sump or into the laboratory standard weigh-tank. Fig. 11 is a diagram of the system. Fig. 12 shows the pine-line, and Fig. 13 the control valve, diverter, and weigh-bridge.

The pipe-line was made up in 25-foot lengths, and the electrodes and injection valve were mounted in 1-foot lengths of pipe which could
Les essais en laboratoire ont été effectués sur une conduite de $508 \mathrm{~mm}$ de diamètre, d'une longueur totale de $213 \mathrm{~m}$, disposée sous forme de deux bras de $107 \mathrm{~m}$ de long. L'alimentation de la conduite était assurée par un bac à niveau constant permettant de maintenir la pression dans la conduite à $11,58 \mathrm{~m}$ d'eau $\pm 3,17 \mathrm{~mm}$. Le déhit passait par une vanne de commande et un dispositif permettant de la diriger soit dans un bac, soit dans la capacité de la bascule de laboratoire. L'installation est représentẻe schématiquement par la figure 11; la figure 12 représente la conduite, ef la figure 13 la vanne de commande, le dispositif de dérivation, et la bascule.

La conduite était constituée d'éléments de $7,62 \mathrm{~m}$ de long, et les électrodes et la soupape d'in- 


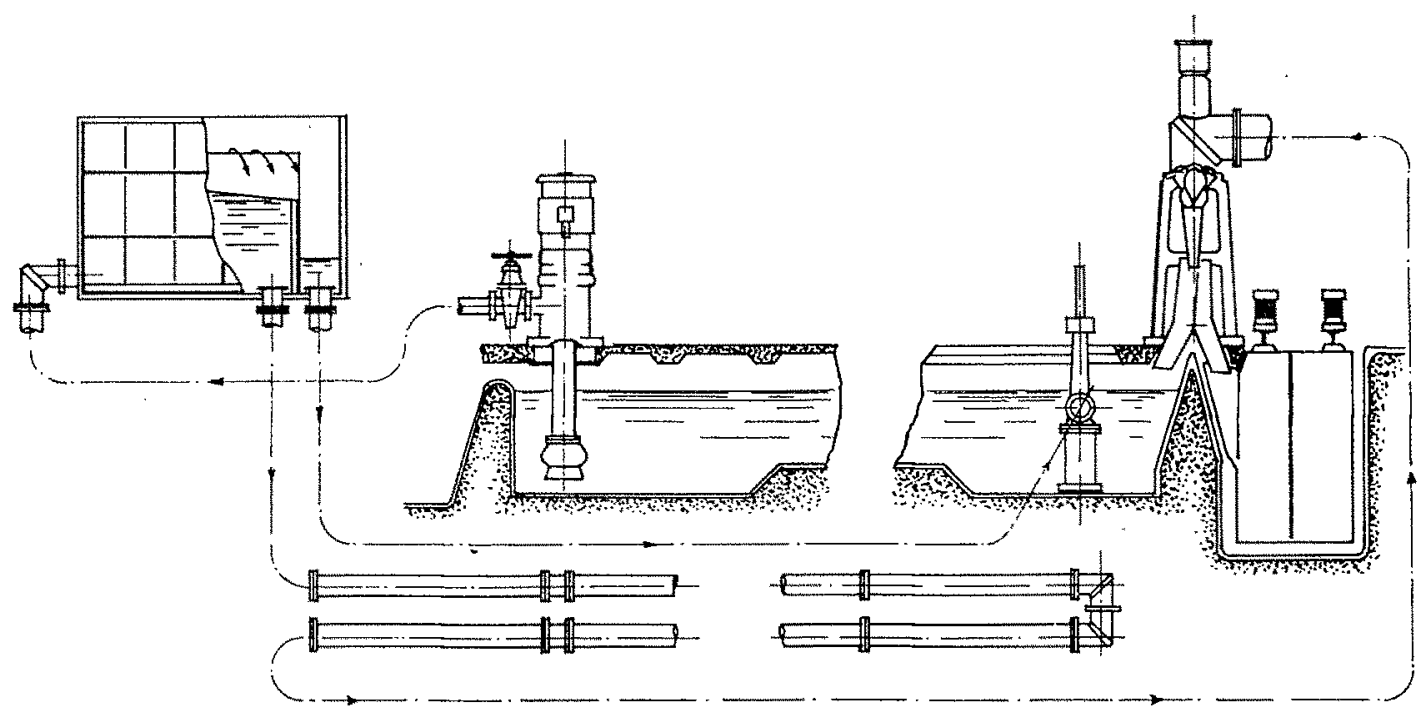

Fio. 11. Laboratory test circuit

Circuit d'essai en laboratoire

be inserted as desired between the main pine lengths. The spacings between the injection valve and electrodes, and between the electrodes themselves, were varied in multiples of 25 feet (approximately) from 25 feet to 125 feet. During the erection of the pipe-line, measurements were made to determine the mean diameters of the 25-foot lengths of pipe over the region where it was proposed to conduct the tests, so that the volume between the electrode stations could be calculated for any of the configurations used.

In carrying out a particular series of tests, the lollowing procedure was adopted : the con- jection étaient montés sur des éléments de $30 \mathrm{~cm}$ de long pouvant être insérés en position voulue entre les éléments principaux de la conduite. Les intervalles entre la soupape d'injection et les électrodes d'une part, et entre les électrodes ellesmêmes d'autre part, ont été choisis comme multiples de 7,6 m environ, allant de 7,6 à 38 mètres. Des mesures ont été effectuées pendant le montage de la conduite, afin de déterminer les diamètres moyens des éléments de conduite de $7,6 \mathrm{~m}$ dans la zone où l'on envisageait d'effectuer les essais, afin de permettre le calcul du volume entre les emplacements des deux paires d'électrodes pour toutes les dispositions utilisées.

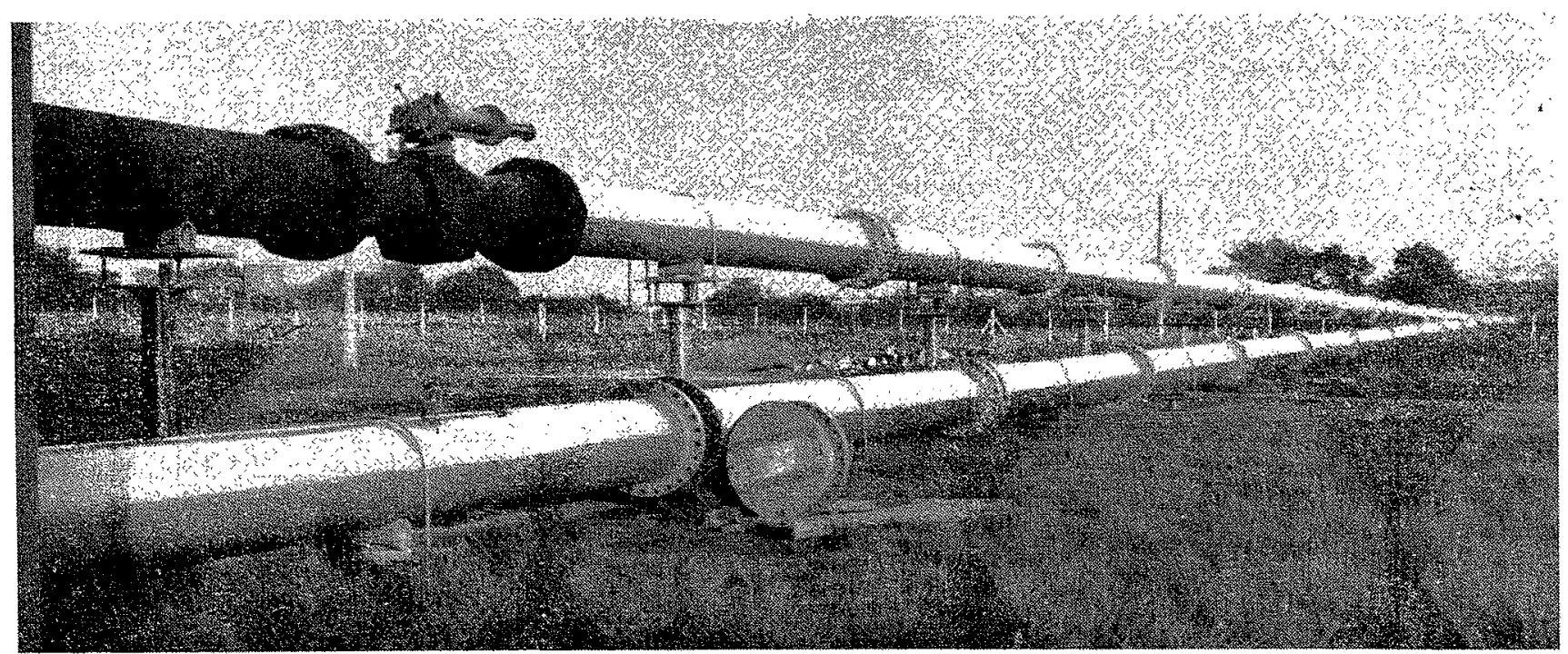

Fia. 12. 20-inch pipe-line used for laboratory tests Conduite de $508 \mathrm{~mm}$ employée pour les essais de laboratoire 
Fig. $13 a$ Control valve and diverter

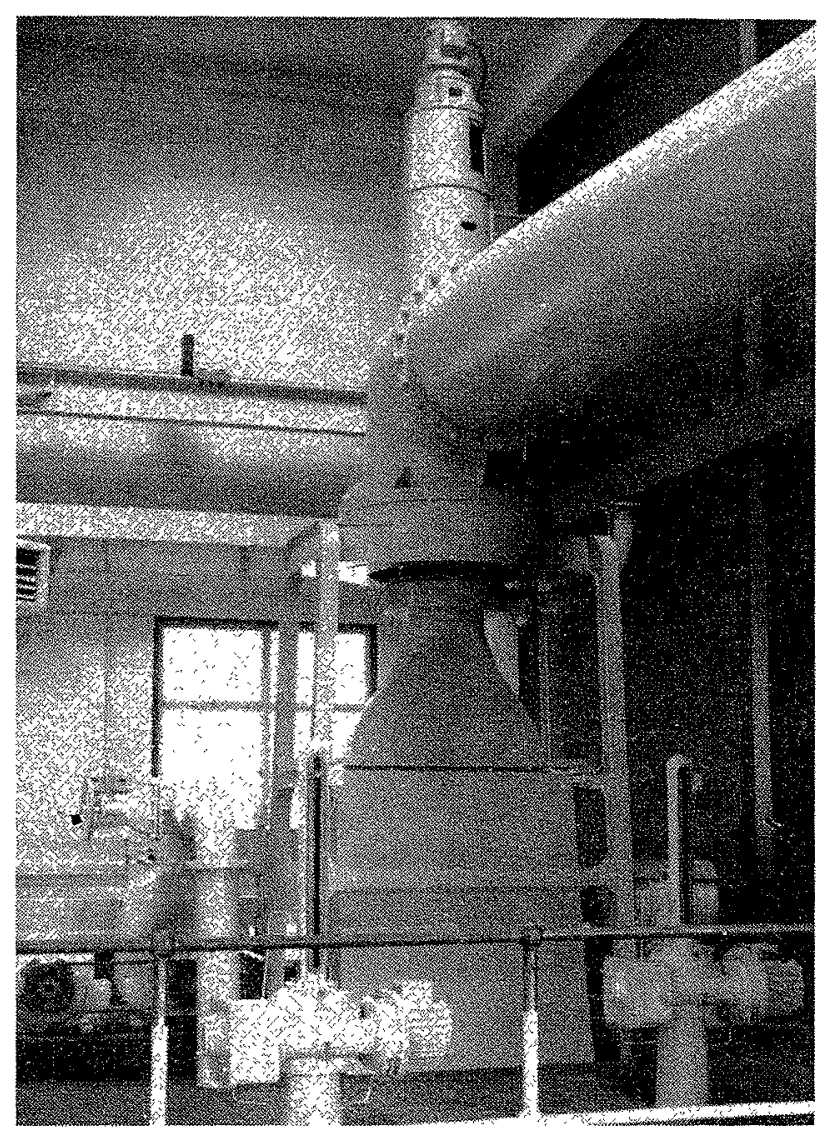

Vanne de commande et dispositif de déftection

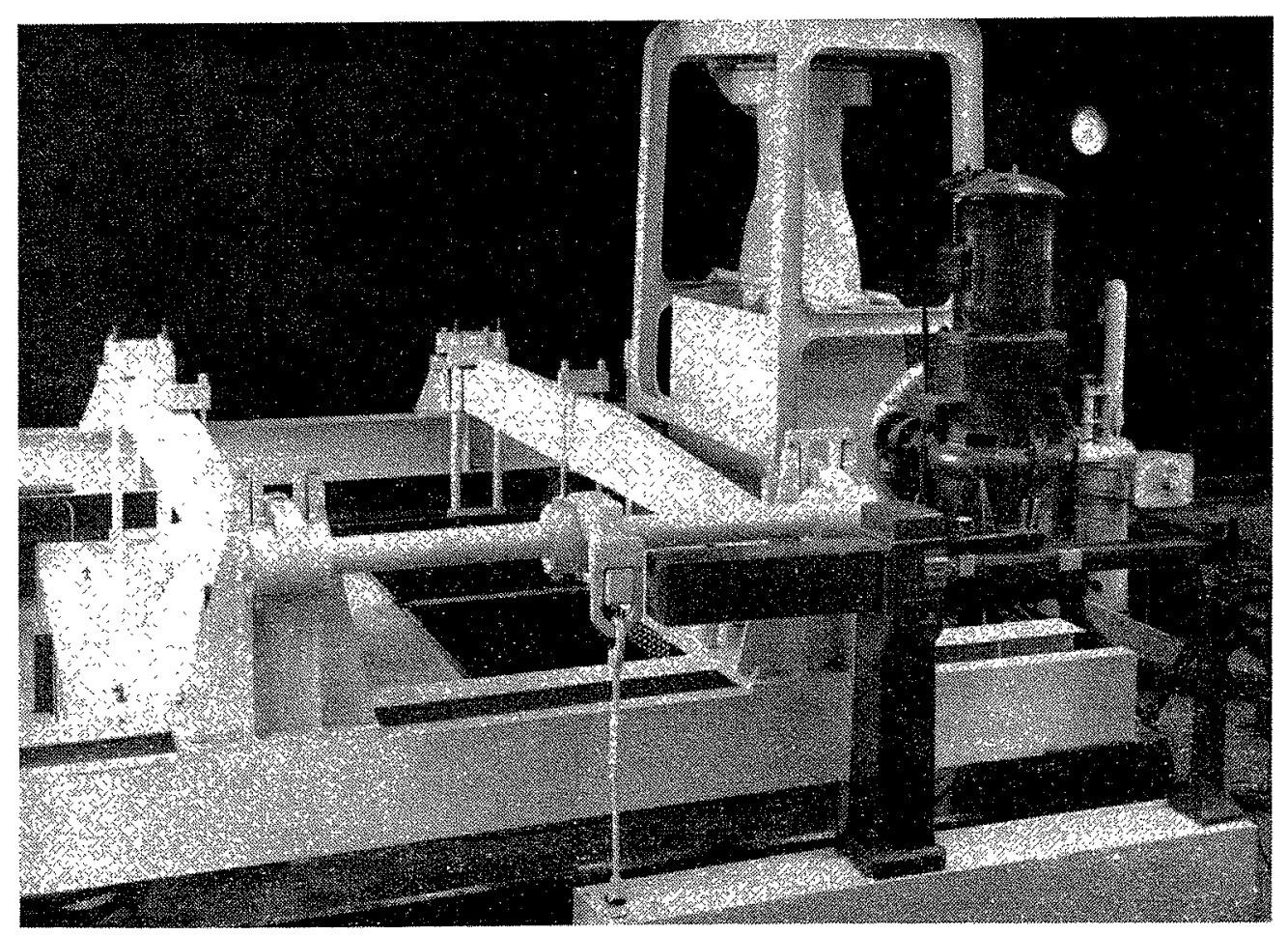

Fig. 13 b. Laboratory standard weigh-tank

Capacité à bascule de laboratoire 
trol valve was adjusted to give the desired flow, and repeated weighbridge measurements were made until successive weighings showed the flow had settled to a steady value. From this time onward, continuous weighbridge measurements were recorded until the series was completed.

The bridges coupled to the two pairs of electrodes were balanced, and trial injections made to establish the amplifier gain settings required to obtain satisfactory oscillograph deflections. on the average, about five injections were needed for this purpose. For the tests proper, approximately twenty injections were made for each series, and after a little practice it was found possible to maintain a rate of one injection per minute without undue strain.

For each configuration of injection valve and electrodes, two complete series of tests were made, one with a flow of approximately 19 cubic feet per second, and one with a flow of approximately 4.5 cubic feet per second (Reynolds numbers $11.8 \times 10^{5}$ and $2.8 \times 10^{5}$ ). In all 17 different configurations, were used, giving a total of 34 test series and 610 individually recorded points. No difficulty in obtaining satisfactory records was encountered at any time. This was very encouraging, since the laboratory water supply was treated with a corrosion inhibiter, and had a conductivity of approximately $4 \times 10^{-3}$ reciprocal ohms per centimetre.
Le procédé adopté pour une série d'essais quelconque ćtait le suivant: on réglait d'abord la vanne de commande pour fournir le débit voulu, et on effectuait ensuite des mesures successives avec la bascule jusqu'à ce que les résultats montrassent que le débit avait atteint une valeur uniforme. A partir de ce moment, on enregisrait continuellement des mesures à la bascule jusqu'à l'achèvement de la série d'essais.

Les ponts raccordés aux deux paires d'électrodes étaient équilibrés, et des injections préliminaires faites pour déterminer le réglage de l'amplification permettant d'obtenir de bonnes déviations sur l'oscillographe. II fallait en moyenne environ cinc injections pour arriver à ce stade. Pour les essais proprement dits, environ une vingtaine d'injections étaient faites pour chaque série, et il devint possible, par la suite, de maintenix la cadence d'une injection par minute, sans trop de fatigue.

Deux séries complètes d'essais ont été effectuées pour chaque disposition de la soupape d'injection et des électrodes, dont l'une avec un débit d'environ $5381 / \mathrm{s}$, et l'autre avec un débit d'environ $127 \mathrm{l} / \mathrm{s}$. (Nombres de Reynolds correspondants : $11,8,10^{\circ}$ et $2,8.10^{\circ}$.) 17 dispositions différentes ont été essayées en tout, ce qui correspond à un total de 34 séries d'essais et 610 points de mesures individuelles. Il n'y a jamais eu de difficultés à obtenir de bons enregistrements, ce qui était très prometteur, étant donné que l'eau d'alimentation du laboratoire était traitée avec un produit anti-corrosif et possédait une conductivité d'environ $4 \cdot 10^{-3}$ ohms par centinetre.

\section{4. - FIELD TESTS}

\section{4. - ESSAIS INDUSTRIELS}

\section{1. - Location and general conditions.}

Since investigation of a number of methods for field flow-measurement formed an important part of the Laboratory's research programme, considerable trouble was taken at an early stage to find an installation where as many of the methods as possible could be employed simultaneously, and their results compared. The most suitable site proved to be at the British Aluminium Company's Kinlochleven reduction works, where, thanks to the interest and cooperation of the Company, it was possible to carry out a comprehensive series of experiments. During the tests described in this report, observations of the flow by current-meters were also taken,

\section{1. - Implantation et conditions générales.}

Etant donné que l'étude d'un certain nombre de méthodes de jaugeages de débit industriel constituait une partie importante du programme de recherches du Laboratoire, on a fait, dès le début, un effort considérable pour trouver une installation permettant d'employer simultanément le plus grand nombre possible de méthodes différentes et d'en comparer les résultats. L'installation de réduction de Ia British Aluminium Company à Kinlochleven fut reconnue être le meilleur endroit pour ce genre d'essais et grâce à l'intérêt et à la coopération de cette Compagnie, il ful possible d'y réaliser une série contplète d'expériences. Pendant los essais décrits 
so that a direct comparison between the two methods was possible.

The hydro-electric installation at Kinlochleven is fully described by Roberts [5]. Briefly, water impounded in the Blackwater reservoir is conveyed by a channel approximately 8 feet square to an intake tank, from which 6 pipes 1 metre in diameter and 1 1/4 miles long descend some 900 feet to the power-house. Fig. 14 shows a general view of the pine lines. Since the power developed is used to supply aluminium smelting dans le présent mémoire, des mesures de débit ont également été effectuées avec des moulinets hydrométriques, permettant ainsi une comparaison directe entre les deux méthodes.

L'installation hydro-électrique de Kinlochleven a fait l'objet d'une description complète par Roberts [5]. Dans cette installation, un bassin d'amenée est alimenté à partir du réservoir de Blackwater par un canal, d'une section carrée d'environ $2,4 \times 2,4$ mètres, le bassin d'amenée étant relié à la centrale à environ $275 \mathrm{~m}$ plus bats, par 6 conduites de 1 mètre de diamètre et d'une longueur de $2 \mathrm{~km}$. La figure 14 montre la dis-

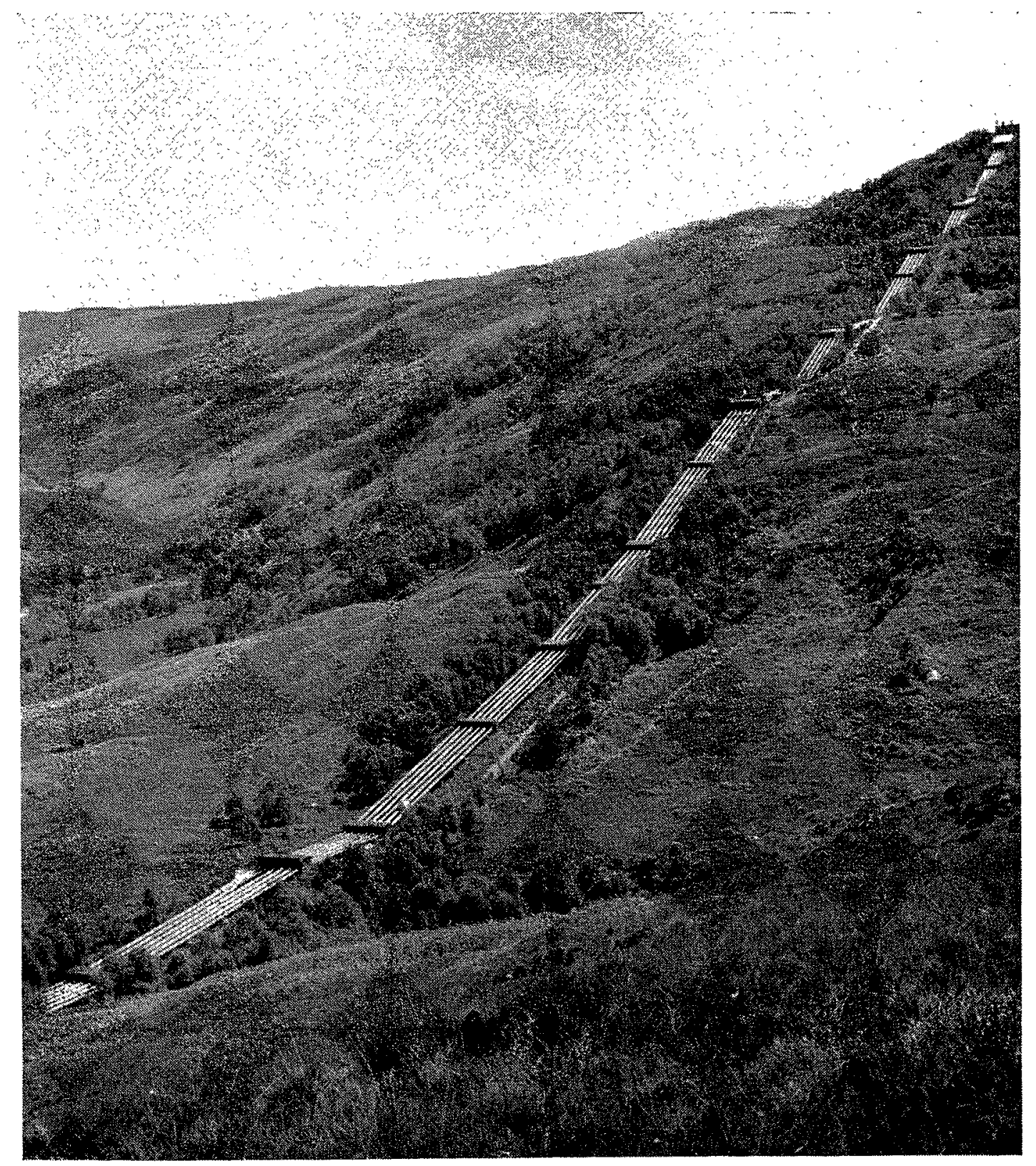

FIG. 14. Pipe-line at British Aluminium Company's Kinlochleven works Conduite des usines de la British Aluminium Company à Kinlochleven 


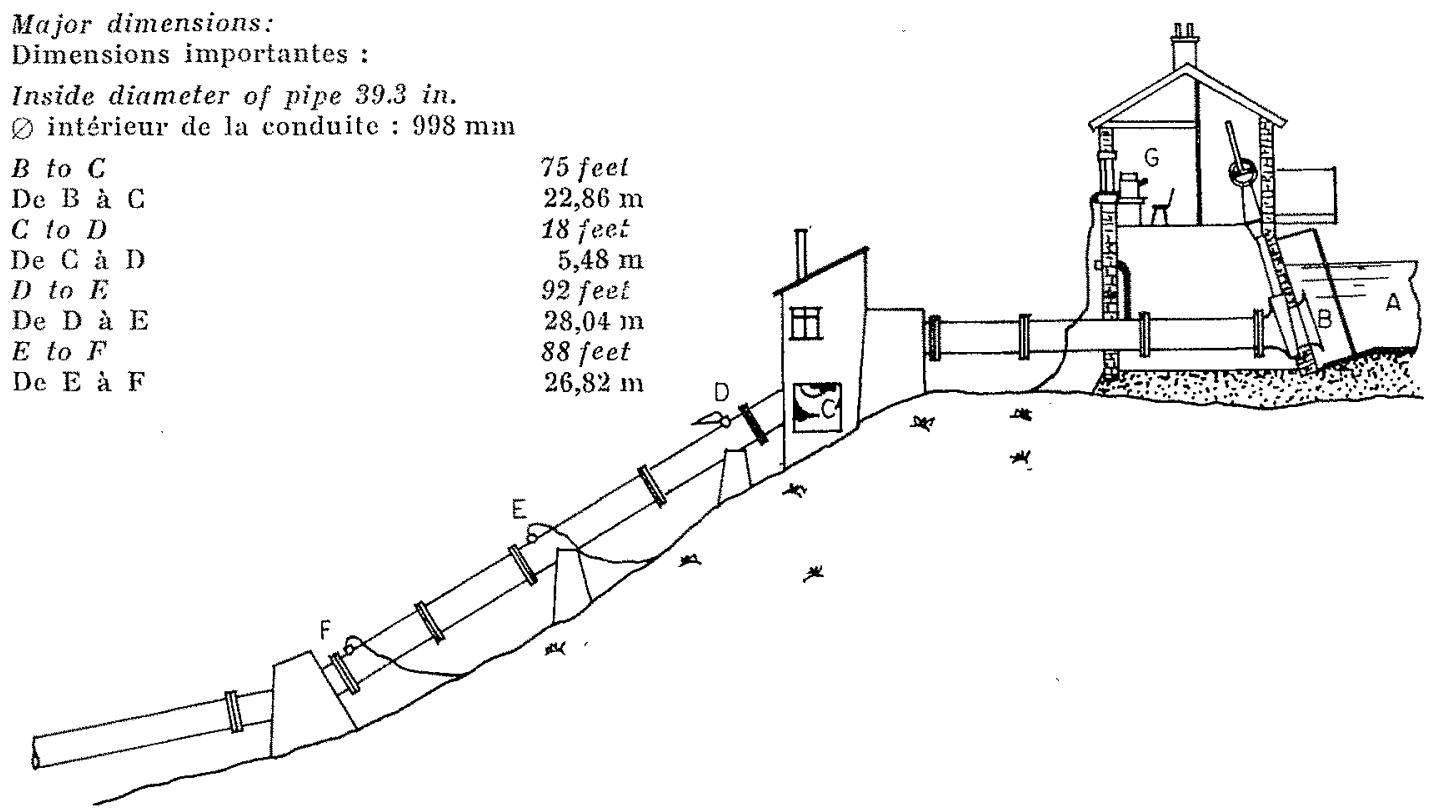

Fra. 15. Field test site (Kinlochleven)

Installation d'essais industriels (Kinlochleven)
A. Intake tank:
B. Shaice valve
C. Emergency butterfly valve
D. Salt injection valve
E. First electrode station
F. Second electrode station
G. Control room

furnaces, the load remains extremely steady for relatively long periods (of the order of two or three days) and the flow is thus also extremely steady.

Stations far salt-velocity flow measurement were installed in one pipe at its upper end, just below the valve house controlling entry from the intake tank to the pipe lines. The layout is shown diagrammatically in Fig. 15. Positions for the electrodes relative to the injection valve were chosen to suit the conditions of the site, on the basis of experience in the laboratory tests.

\section{2. - Battery-operated detection apparatus.}

As mentioned in Section 2.1 above, transistor oscillator/amplifier units supplied from $30 \mathrm{v}$ batteries were used during the field tests, though the mains-operated units were also taken as a stand-by. As this time mains-operated oscillographs were still required, though as mentioned

\author{
Réservoir d'arrivée \\ Vanne de garde \\ Vange-papillon de secours \\ Soupape d'injection de la solution de sel \\ Première station d'électrodes \\ Deuxième station d'électrodes \\ Salle de commande
}

position générale de ces conduites. La puissance cngendrée servant à alimenter des fours de fonderie d'aluminium, la charge reste extrêmement uniforme pendant les périodes relativement longues (de lordre de deux ou trois jours) et le débit est ainsi extrêmement régulier.

Des stations de jaugeage. par écran salé ont été installées à l'extrémité supérieure de l'une des conduites, juste au-dessous du bâtiment des vannes commandant l'entrée $d u$ bassin d'amenée aux conduites forcées. Cette disposilion est représentée schématiquement par la figure 15 . Les positions des électrodes par rapport à la soupape d'injection ont été choisies de manière à convenir anx conditions du site, sur la base de l'expórience acquise pendant les essais de laboratoire.

\section{2. - Dispositif de détection à alimenta- tion par batterie.}

Comme il a été mentionné dans la section 2.1 ci-dessus, des groupes oscillateurs-amplificateurs à transistors, alimentés par des batteries de 30 volts, ont été utilisés pour les essais industriels, mais on a également pris des appareils à alimentation par le secteur comme équipement de secours. A l'époque de ces essais, il était encore 


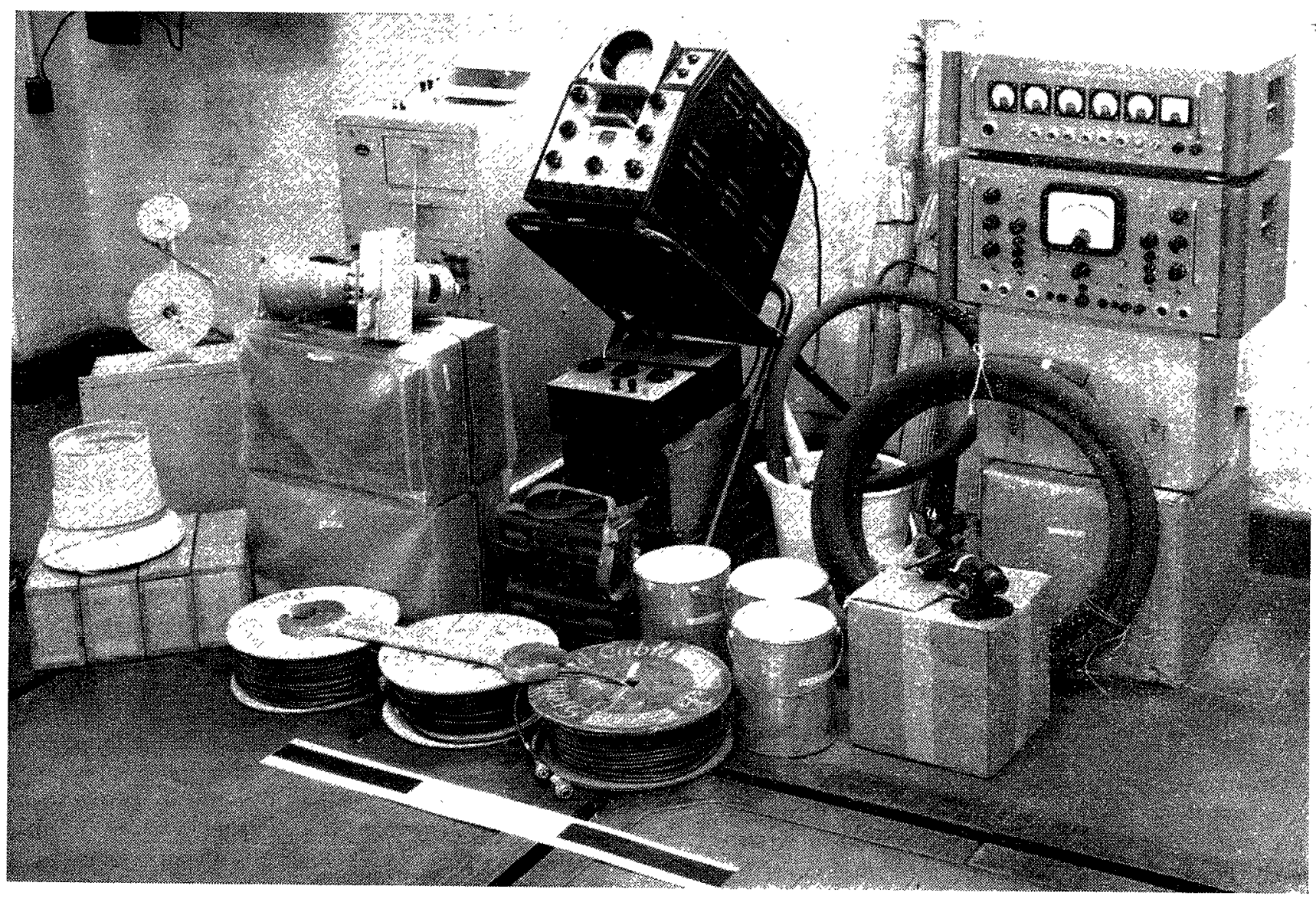

Frg. 16. Equipment assembled for transport to field tests Appareils rassemblés pour leur transport aux essais industricls

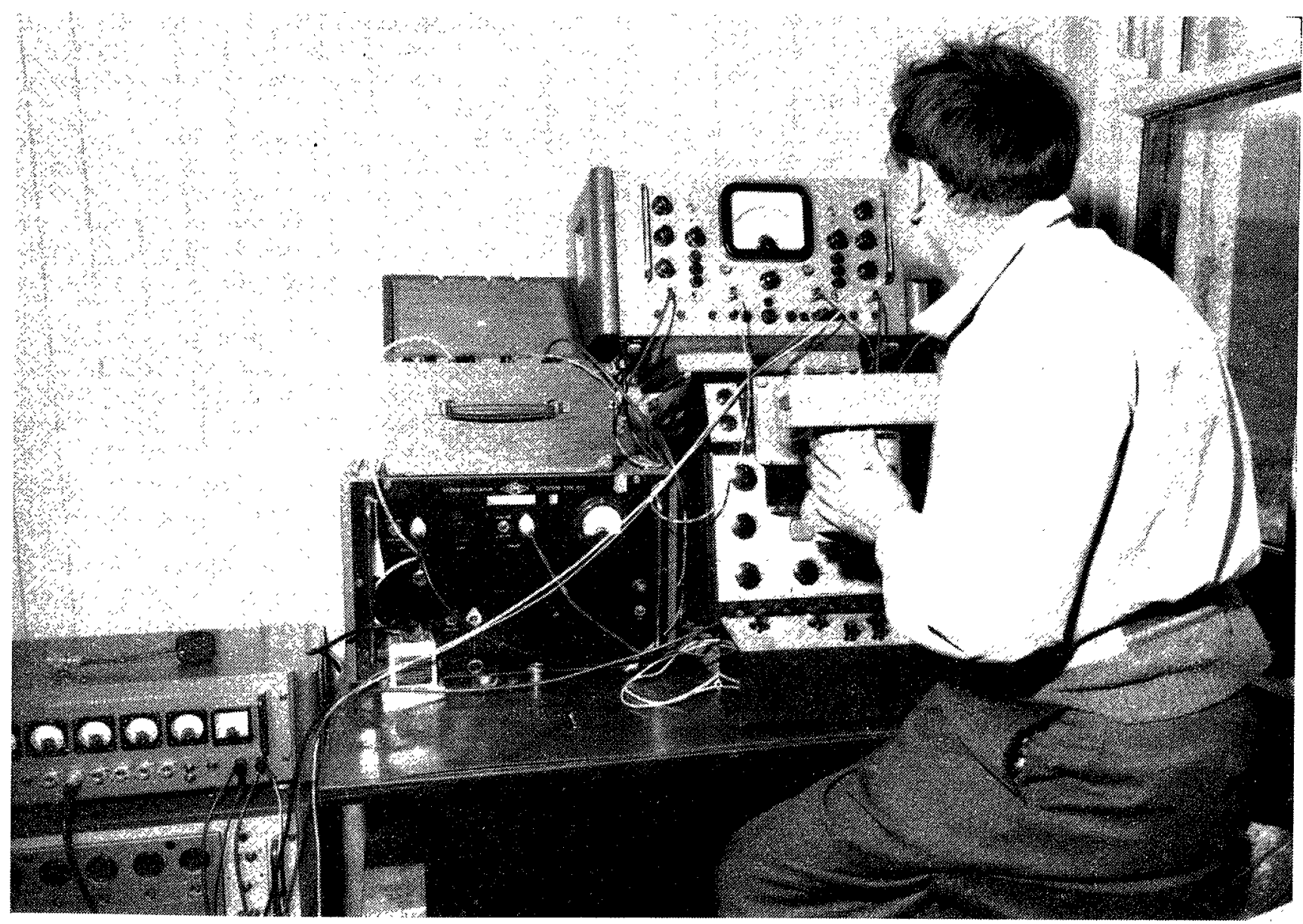

FI. 17. Detection equipment installed for field tests

Appareils de détection installés pour les essais industriels 
in Scction 7.1 below, later developments have resulted in the production of a complete batteryoperated system.

\section{3. - Installation and tests.}

The whole of the equipment used in the field lests is shown assembled ready for transport in Fig. 16. It should be emphasized that nearly twice as much is shown as would normally be necessary, since two sets of amplifiers and oscillators and two oscillographs (pen and cathoderay) were taken. A complete list of items, together with quantities of material consumed, is given in the Appendix.

On arrival at the site, the electrical equipment was installed in the valve house, and the cables run out to the electrode stations. Meanwhile, the pipe had been entered, and measurements of diameter in two directions at right angles were taken at 30 points between the electrodes by means of a special measuring rod. Fig. 17 shows the equipment installed in the valve house.

During the tests proper, the operating procedure was exactly the same as described in Section 3 for the laboratory experiments. No difficulties were encountered in finding and maintaining the bridge balance or in establishing amplifier gain settings, and satisfactory records were obtained throughout.

Measurements were made at two different flow rates, ohtained by running approximately the same volume of water through six and five pipelines. (This was possible because the turbines in the power house are fed from bus pipes supplied by all the main pipes.)

A total number of fourteen test series was taken, with eight to ten individual injections in each series, this number having been estimated from a statistical analysis of the laboratory results to be the minimum which would give 95 per cent confidence limits of error of \pm 1 per cent.

It was found possible to complete a test series in an average time of 10 minutes, confirming the experience in the laboratory. The injection valve runctioned without attention for a total of 310 cycles, and was in good condition when stripped for examination after the tests. nécessaire d'utiliser des oscillographes alimentés par le secteur, mais on a pu, depuis, mettre au point un système entier fonctionnant sur batteries (voir section 7.1).

\section{3. - Installation et essais.}

La figure 16 montre l'ensemble des appareils utilisés pour les essais industriels prêts pour le transport à pied d'œuvre. A noter que cet équipement représente presque le double de ce qui serait normalement nécessaire, puisque denx ensembles d'amplificateurs et d'oscillateurs et deux oscillographes (à plume et à tubes cathodiques) ont été emmenés pour ces essais. Le lecteur trouvera une liste complète de cet équipement, et une indication de volume des matières consommées, dans l'annexe au présent mémoire.

Les appareils électriques ont été installés dans le bâtiment des rannes dès leur arrivée à pied d'œuvre, et les câbles les reliant aux électrodes ont également été installés. Entre temps, des mesures du diamètre à l'intérieur de la conduite avaient été effectuées dans chaque cas sur deux diamètres perpendiculaires l'un à l'autre, en une trentaine de points, entre les électrodes, an moyen d'une perche de mesures spéciale. La figure 17 montre l'appareillage installé dans le bâtiment des vannes.

Pendant les essais proprement dits, le procédé a élé exactement tel que celui décrit dans la section 3 pour les essais en laboratoire. II n'y eut aucune difficulté à déterminer et à maintenir l'équilibre du pont, ou à régler le gain de l'amplificateur; tous les enregistrements obtenus étaient satisfaisants.

Les mesures ont été effectuées pour deux débits différents, qui furent obtenus en faisant passer à peu près le même volume d'eau par 6 et 5 des conduites forcées (il dtait possible d'agir ainsi, parce que les turbines de la centrale sont alimentées à partir de collecteurs, eux-mêmes alimentés par l'ensemble des conduites principales).

14 séries d'essais ont été réalisées en tout, dont chacune comportait entre 8 et 10 injections individuelles, ce nombre ayant été fixé par une analyse statistique des résultats obtenus en laboratoire, comme étant le nombre minimum pouvant garantir avec $95 \%$ de sécnrité des limites d'erreur de mesure de $\pm 1 \%$.

Il a été reconnu possible d'effectuer une série d'essais dans un temps moyen de dix minutes, ce qui confirmait les expériences de laboratoire. La soupape d'injection a fonctionné sans nécessiter un entretien queleonque pendant 310 cycles; elle était encore en bon état lors du démontage de contrôle après les essais. 


\section{4. - Evaluation of field-tests results.}

The records from the cathode-ray oscillograph were obtained on 25-foot lengths of 35-millimetre film. These were conveyed by road transport from the measuring station to the reduction works, where a dark room was available. Processing was carried out with standard microfilm equipment, and the dry films were ready for analysis 30 minutes after their arrival at the dark room. It was found possible to evaluate all the films from one test period (comprising four or five separate series) before the next was started.

Since a d.c. output was available from the transistor amplifier equipment, a two-channel high-speed pen recorder was used as well as
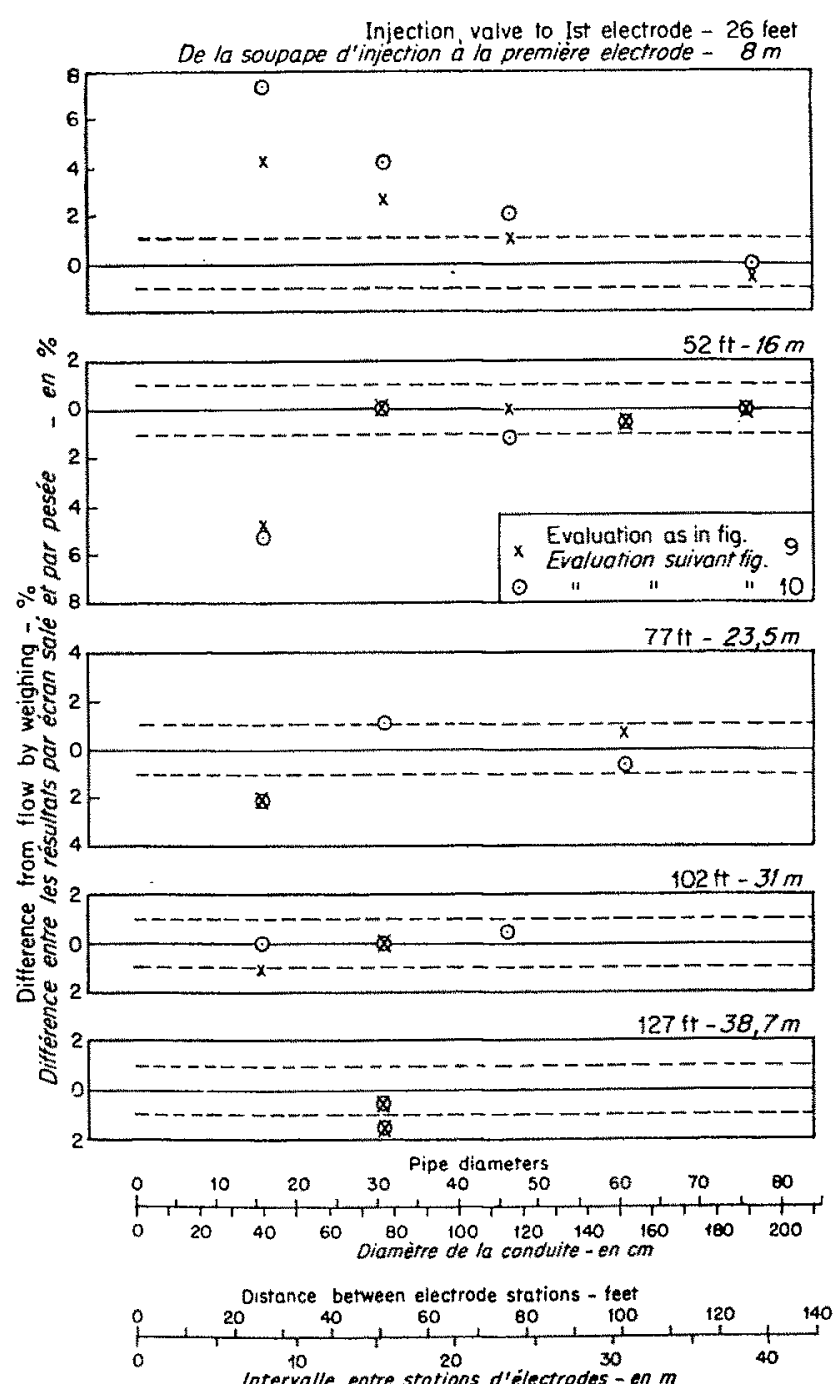

FIG. 18. Salt-velocity measurement in laboratory 20-inch pipe-line. Flow approx. 18 cusecs

Mesures par écran salé dans une conduite de laboratoire de $508 \mathrm{~mm}$. Débit approximatif $510 \mathrm{l} / \mathrm{s}$

\section{4. - Dépouillement des résultats des essais industriels.}

Les enregistrements de l'oscillographe à tube cathodique ont été obtenus sous forme de bandes de pellicule de $35 \mathrm{~mm}$ ayant une longueur de $7,6 \mathrm{~m}$ chacune. Ces enregistrements ont été envoyés par camion à l'usine de réduction, oì l'on disposait d'une chambre noire. Le développement s'est effectué avec un écruipement de microfilm classique, et les films étaient séchés et disponibles pour l'analyse 30 minutes apris leur arrivée à la chambre noire. Il a ainsi été possible de dépouiller tous les films obtenus pendant une période d'essais donnée (comprenant 4 ou 5 séries séparées), avant le début de la période suivante.

Grâce à une sortie en courant continu du groupe amplificateur à transistors, on a pu em-

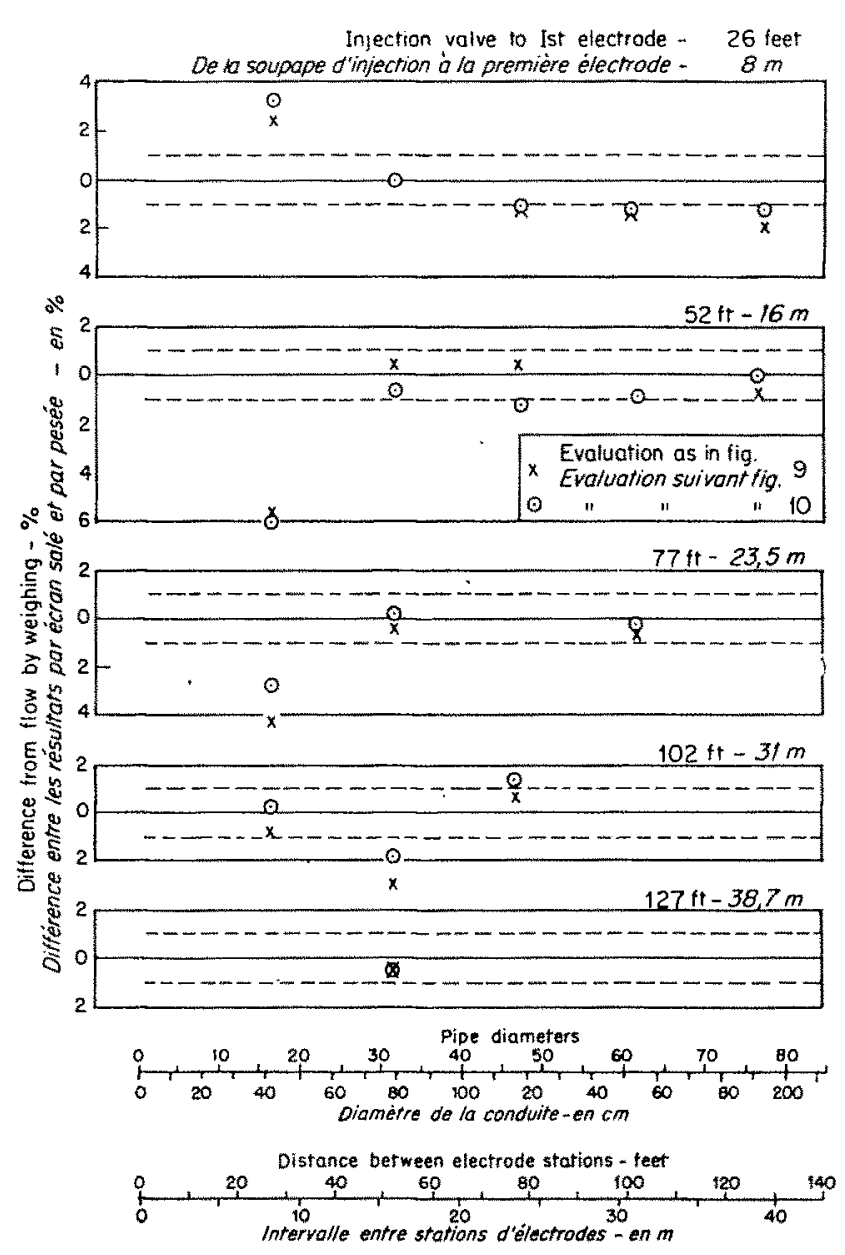

Fig. 19. Salt-velocily measurements in laboratory 20-inch pipe-line. Flom approx. 4.5 cusecs

Mesures par écran salé dans une conduite de lahoratoire de $508 \mathrm{~mm}$. Débit approximatif $127 \mathrm{l} / \mathrm{s}$ 
cathode ray oscillograph. In this way, visible records were oblained immediately. A timing pulse from the transistor frequency standard was superimposed on one of the pens, so that these records could be used to evaluate results. Using the new method of analysis (Fig. 10), the flow could be obtained from them about 4 minutes after an injection. The results obtained from pen records covering part of the field tests are shown in Table 2 for comparison with those from the film records. ployer un enregistrement à plumes à grande vitesse, à 2 voies, pour compléter l'oscillographe à tube cathodique, obtenant ainsi immédiatement des indications visuelles. Une pulsation de temporisation fournie par l'ćtalon de lréquence à transistors était superposće à l'une des plumes, afin de permettre l'utilisation de ces enregistrements pour éraluer les résultats. En utilisant la nouvelle méthode d'analyse (fig. 10), il était possible de déterminer le débit à partir de ces résultats, environ quatre minutes après chaque injection. Les résultals obtenus des enregistrements par plumes correspondant à une partie des essais industriels sont indiqués an tableau 2 pour en permettre la comparaison avee les enregistrements photographiques.

\section{5. - DISCUSSION OF RESULTS \\ 5. - DISCUSSION DES RÉSULTATS}

\section{1. - Laboratory tests.}

The results of the experiments in the laboratory are given in Table 1 and are shown giraphically in Figs. 18 and 19.

\section{INHFRENT ERROR.}

Before considering the results of the experiments in detail, it is necessary to examine the error's which may be inherent in them. The two unavoidable systematic errors were in the determination of the volume of pipe helween the electrode slations, and in the measurement of flow by the laboratory weighbridge. There was also a possibility of a systematic error in the measurement of the oscillograph records due to personal bias in the observer.

So far as the rolume between the electrode stations was concerned, a careful examination was made of the measurements of pipe rliameter, and it was concluded that the mean diameter of any of the lengths used could be determined to 0.05 inch, giving 95 per cent confidence limits of error of $\pm 1 / \mathrm{A}$ per cent in the mean area. For measurement of the distance between the electrode stations a standard steel tape was used, giving easily results to within 0.5 inch, so that the error was not more than 1 part in 600 on 25 leet, the shortest length used. The possible error in pipe volume can thercfore reason-

\section{1. Essais en laboratoire.}

Les résultats des essais en laboratoire sont donnés dans le tableau 1 et représentés sous forme graphique dans les figures 18 et 19 .

\section{Erreurs inhérentes.}

Avant de considérer en détail les résultats des essais, il est nécessaire d'examiner les erreurs qui $y$ seraient éventuellement inhérentes. Les deux erreurs systématiques inévitables araient trait à la détermination du volume de la conduite entre les paires d'électrodes, et à la mesure du débit au moyen de la bascule du laboratoire. Il y avait également la possibilité d'une erreur systématique dans la mesure des enresistrements oscillographiques, due à l'équation personnelle de l'opérateur.

Fn ce qui concerne le volume compris entre les paires d'électrodes, les mesures de diamòtre de la conduite ont été examinćes soignneusement, of on a conolu que le diamètre moyen de n'importe quels éléments de conduite ulilisés pouvait être déterminé à $1,27 \mathrm{~mm}$ près, ce crui correspond à des limites d'erreur à $95 \%$ de confiance de $\pm 0,25 \%$ dans la section moyenne. La distance entre les paires d'électrodes a été mesurée au moyen d'un ruban d'acier standard donnant facilement des résultats prócis à $12,7 \mathrm{~mm}$ près, de sorte que l'erreur ne déplassait pas la proportion de $1 / 600^{\circ}$ pour une longueur de $7,60 \mathrm{~m}$, celte longueur étant la plus petite que l'on ait utilisce. On peut donc admethe que lerreur possible dans la diterminalion du volume de la conduite étail de $\pm 0,25 \%$, ceci avec $95 \%$ de sécurité. 
TABLEAU 1. - JAUGEAGE DES DÉBITS PAR ÉCRAN SALE. - ESSAIS EN LABORATOIRE.

TABLE 1. - SALT-VELOCITY FLOW MEASUREMENT. - LABORATORY EXPERIMENTS

Débits en pieds cubes par seconde Flow. Cubic feel per second

\begin{tabular}{|c|c|c|c|c|c|c|c|c|c|}
\hline \multicolumn{2}{|c|}{$\begin{array}{l}\text { Intervalles, en pieds } \\
\text { System spacing, feet }\end{array}$} & \multirow[b]{2}{*}{ 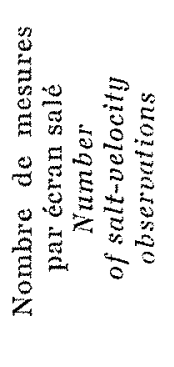 } & \multirow[b]{2}{*}{ 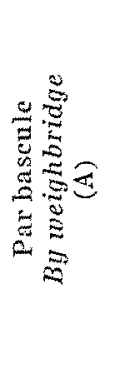 } & \multicolumn{2}{|c|}{$\begin{array}{c}\text { Ecran salé, méthode } 1 \\
\text { Salt-velocity by method } 1\end{array}$} & \multicolumn{2}{|c|}{$\begin{array}{c}\text { Eeran salé, méthode } 2 \\
\text { Salt-velocity by method } 2\end{array}$} & \multicolumn{2}{|c|}{$\begin{array}{l}\text { Différences } \\
\text { Differences }\end{array}$} \\
\hline 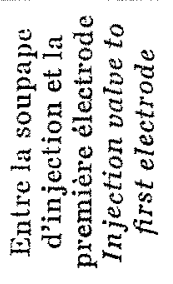 & 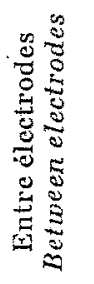 & & & 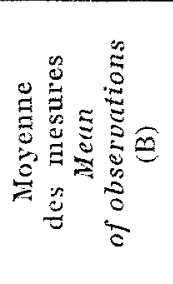 & 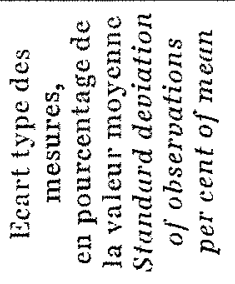 & 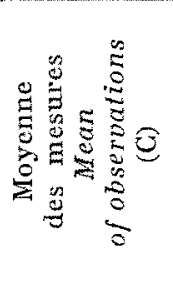 & 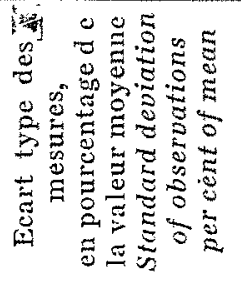 & $\left.\frac{a}{1}\right|^{a}$ & 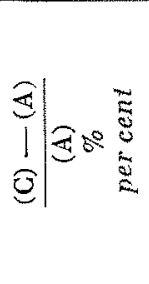 \\
\hline 26 & 26 & $\begin{array}{l}19 \\
17\end{array}$ & $\begin{array}{c}18,9 \\
4,50\end{array}$ & $\begin{array}{c}19,7 \\
4,61\end{array}$ & $\begin{array}{l}2,02 \\
2,24\end{array}$ & $\begin{array}{l}20,3 \\
4,65\end{array}$ & $\begin{array}{l}2,09 \\
2,64\end{array}$ & $\begin{array}{l}+4,23 \\
+2,44\end{array}$ & $\begin{array}{l}+7,6 \\
+3,33\end{array}$ \\
\hline 26 & 51 & $\begin{array}{l}19 \\
20\end{array}$ & $\begin{array}{c}18,9 \\
4,62\end{array}$ & $\underline{19,4}$ & $\underline{1,61}$ & $\begin{array}{c}19,7 \\
4,62\end{array}$ & $\begin{array}{l}1,17 \\
2,90\end{array}$ & $+\underline{2,65}$ & $\begin{array}{c}+4,23 \\
0\end{array}$ \\
\hline 26 & 77 & $\begin{array}{l}20 \\
19\end{array}$ & $\begin{array}{c}18,9 \\
4,81\end{array}$ & $\begin{array}{c}19,1 \\
4,75\end{array}$ & $\begin{array}{l}0,88 \\
1,00\end{array}$ & $\begin{array}{c}19,3 \\
4,76\end{array}$ & $\begin{array}{l}1,12 \\
0,66\end{array}$ & $\begin{array}{r}+1,06 \\
-1,25\end{array}$ & $\begin{array}{r}+2,12 \\
-1,04\end{array}$ \\
\hline 26 & 102 & $\begin{array}{l}20 \\
21\end{array}$ & $\begin{array}{c}18,7 \\
4,83\end{array}$ & $\begin{array}{c}18,7 \\
4,81\end{array}$ & $\begin{array}{l}0,93 \\
0,91\end{array}$ & $\begin{array}{c}18,7 \\
4,82\end{array}$ & $\begin{array}{l}0,63 \\
0,50\end{array}$ & $\begin{array}{c}0 \\
-0,41\end{array}$ & $\begin{array}{l}0 \\
0,22\end{array}$ \\
\hline 26 & 127 & $\begin{array}{l}20 \\
17\end{array}$ & $\begin{array}{c}19,0 \\
4,36\end{array}$ & $\begin{array}{c}18,9 \\
4,28\end{array}$ & $\begin{array}{l}0,57 \\
0.63\end{array}$ & $\begin{array}{c}19,0 \\
4,31\end{array}$ & $\begin{array}{l}0,54 \\
0,47\end{array}$ & $\begin{array}{r}-0,53 \\
-1,83\end{array}$ & $\begin{array}{l}0 \\
-1,15\end{array}$ \\
\hline 5̆1 & 26 & $\begin{array}{l}20 \\
17\end{array}$ & $\begin{array}{c}19,0 \\
4,47\end{array}$ & $\begin{array}{c}18,1 \\
4,22\end{array}$ & 1,63 & $\begin{array}{c}18,0 \\
4,17\end{array}$ & $\begin{array}{l}2,65 \\
3,33\end{array}$ & $\begin{array}{r}4,74 \\
-5,59\end{array}$ & $\begin{array}{r}-5,3 \\
-6,7\end{array}$ \\
\hline 51 & 51 & $\begin{array}{l}18 \\
18\end{array}$ & $\begin{array}{c}19,4 \\
4,43\end{array}$ & $\begin{array}{c}19,4 \\
4,45\end{array}$ & $\begin{array}{l}1,22 \\
1,09\end{array}$ & $\begin{array}{l}19,4 \\
4,40\end{array}$ & $\begin{array}{l}1,45 \\
1,24\end{array}$ & $\begin{array}{l}0 \\
+0,45\end{array}$ & $\begin{array}{c}0 \\
-0,68\end{array}$ \\
\hline 51 & 77 & $\begin{array}{l}23 \\
20\end{array}$ & $\begin{array}{c}18,9 \\
4,10\end{array}$ & $\begin{array}{c}18,9 \\
4,12\end{array}$ & $\begin{array}{l}1,08 \\
0,55\end{array}$ & $\begin{array}{c}18,7 \\
4,05\end{array}$ & $\begin{array}{l}0,57 \\
1,44\end{array}$ & $\begin{array}{l}0 \\
+0,49\end{array}$ & $\begin{array}{r}-1,06 \\
-1,22\end{array}$ \\
\hline 52 & 101 & $\begin{array}{l}20 \\
15\end{array}$ & $\begin{array}{l}18,8 \\
4,50\end{array}$ & $\underline{18,7}$ & $\underline{0,63}$ & $\begin{array}{c}18,7 \\
4,46\end{array}$ & $\begin{array}{l}0,27 \\
0,95\end{array}$ & $--0,53$ & $\begin{array}{r}-0,53 \\
-0,89\end{array}$ \\
\hline ธั2 & 126 & $\begin{array}{l}19 \\
20\end{array}$ & $\begin{array}{l}17,6 \\
4,77\end{array}$ & $\begin{array}{c}17,6 \\
4,74\end{array}$ & $\begin{array}{l}0,44 \\
1,04\end{array}$ & $\begin{array}{c}17,6 \\
4,77\end{array}$ & $\begin{array}{l}0,36 \\
0,51\end{array}$ & $\begin{array}{c}0 \\
-0,63\end{array}$ & $\begin{array}{l}0 \\
0\end{array}$ \\
\hline 77 & 26 & $\begin{array}{l}20 \\
21\end{array}$ & $\begin{array}{c}18,9 \\
5,06\end{array}$ & $\begin{array}{c}18,5 \\
4,83\end{array}$ & $\begin{array}{l}1,78 \\
1,40\end{array}$ & $\begin{array}{c}18,5 \\
4,92\end{array}$ & $\begin{array}{l}2,74 \\
1,89\end{array}$ & $\begin{array}{r}2,12 \\
-\quad 4,54\end{array}$ & $\begin{array}{r}2,12 \\
-2,77\end{array}$ \\
\hline 77 & 51 & $\begin{array}{l}20 \\
15\end{array}$ & $\begin{array}{l}19,0 \\
4,50\end{array}$ & 4,48 & 1,61 & $\begin{array}{c}19,2 \\
4,51\end{array}$ & $\begin{array}{l}0,96 \\
0,97\end{array}$ & $-0,44$ & $\begin{array}{l}+1,05 \\
+0,22\end{array}$ \\
\hline 76 & 101 & $\begin{array}{l}12 \\
14\end{array}$ & $\begin{array}{c}15,0 \\
3,84\end{array}$ & $\begin{array}{c}15,1 \\
3,81\end{array}$ & $\begin{array}{l}1,19 \\
1,19\end{array}$ & $\begin{array}{c}14,9 \\
3,83\end{array}$ & $\begin{array}{l}0,92 \\
1,19\end{array}$ & $\begin{array}{r}0,677 \\
-0,78\end{array}$ & $\begin{array}{r}-0,67 \\
-0,26\end{array}$ \\
\hline 102 & 26 & $\begin{array}{l}21 \\
18\end{array}$ & $\begin{array}{c}18,7 \\
4,83\end{array}$ & $\begin{array}{c}18,5 \\
4,80\end{array}$ & $\begin{array}{l}2,02 \\
1,90\end{array}$ & $\begin{array}{c}18,7 \\
4,84\end{array}$ & $\begin{array}{l}1,94 \\
1,70\end{array}$ & $\begin{array}{r}-1,07 \\
-0,83\end{array}$ & $\begin{array}{c}0 \\
+0,21\end{array}$ \\
\hline 102 & 51 & $\begin{array}{l}18 \\
15\end{array}$ & $\begin{array}{c}18,9 \\
4,98\end{array}$ & $\begin{array}{c}18,9 \\
4,83\end{array}$ & $\begin{array}{l}1,56 \\
1,42\end{array}$ & $\begin{array}{c}18,9 \\
4,89\end{array}$ & $\begin{array}{l}0,91 \\
1,88\end{array}$ & $\begin{array}{c}0 \\
-3,01\end{array}$ & $\begin{array}{c}0 \\
-1,81\end{array}$ \\
\hline 102 & 76 & $\begin{array}{r}19 \\
9\end{array}$ & $\begin{array}{c}18,8 \\
4,13\end{array}$ & $\widetilde{4,46}$ & $\overline{1,00}$ & $\begin{array}{c}18,9 \\
4,49\end{array}$ & $\begin{array}{l}1,39 \\
0,85\end{array}$ & $+\overline{0,68}$ & $\begin{array}{l}+0,53 \\
+1,35\end{array}$ \\
\hline 127 & 51 & $\begin{array}{l}12 \\
12\end{array}$ & $\begin{array}{l}18,9 \\
19,0\end{array}$ & $\begin{array}{l}18,6 \\
18,9\end{array}$ & $\begin{array}{l}1,91 \\
1,11\end{array}$ & $\begin{array}{l}18,6 \\
18,9\end{array}$ & $\begin{array}{l}1,14 \\
1,50\end{array}$ & $\begin{array}{r}-1,59 \\
-1,53\end{array}$ & $\begin{array}{r}-1,59 \\
-0,53\end{array}$ \\
\hline
\end{tabular}


TABLEAU 2. - COMPARAISON ENTRE LES MÉTHODES DE MESURE PAR ÉCRAN SALE ET AU MOULINET

MESURES INDUSTRIELLES

TABLE 2. - COMPARISON OF SALT-VELOCITY AND CURRENT-METER MEASUREMENTS.

FIELD TESTS

Débits en pieds cubes par seconde Rlow. Cubic feet per second

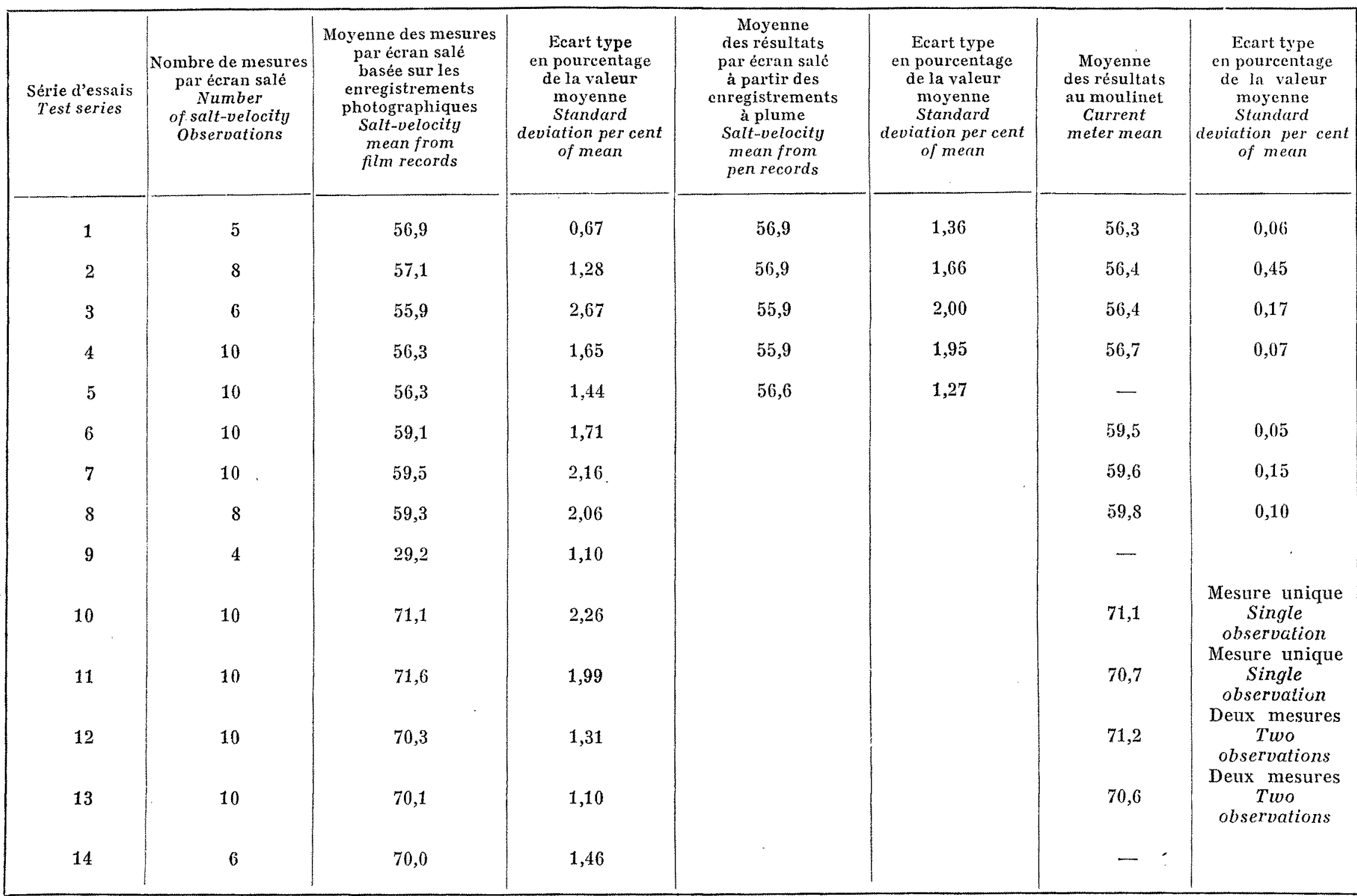

Tous les résultats par écran salé ont été évalués suivant la fig. 10 .

All salt-velocity results evaluated as in fig. 10

Nota: Diamètre de la conduite : $998 \mathrm{~mm}$ ( $\varnothing$ nominal

1 mètre). - Distance entre la soupape d'injection et la

Notes: Pipe diameter-39.3 inches (nominal 1 mètre). Injection valve to 1 st electrode- 92 feet.-1st electrode to 2 nd electrode -88 feet.

première électrode $: 28$ mètres. - Entre la première et

la deuxième électrode : $26,82 \mathrm{~m}$. 
ably be taken as $\pm 1 / 4$ per cent with 95 per cent confidence.

Spencer has undertaken investigations of the errors in flow measurement by the laboratory weighbridge, the results of which will be publised in due course. Based on this work, the 95 per cent confidence limits of error for these tests for a single observation were estimated to be \pm 0.2 per cent at the flow of 18 cubic feet per second, and \pm 0.4 per cent at the flow of 4.5 cubic feet per second. On the average, eight successive measurements were taken during each test at the higher flow rate, and twenty at the lower flow rate. The 95 per cent confidence limits of error for the mean values of the weighbridge measurements could thus be taken as \pm 0.07 per cent and \pm 0.09 per cent respectively. The possible systematic errors in calibration and use of the laboratory flow measurement system are estimated to be less than \pm 0.1 per cent.

To check on personal error in reading the oscillograph records, some of these were analysed hy two different observers. The differences in mean flow calculated by the two observers did not exceed $1 / 4$ per cent, and showed no bias.

\section{Effecis of System Spacing.}

If as a criterion of accuracy a difference of not more than 1 per cent from the flow measured by the weighbridge is taken (which is a reasonable figure taking into account the standard deviations for the sets of observations and the possible systematic errors), it is apparent that conditions immediately downstream of the injection valve are not sufficiently stable to give accurate results with very close spacing of the electrodes.

The results for 26 -feet electrode spacing at dislances from the injection valve of 26,52 and 75 feet all show substantial errors. The results for a first electrode distance of 102 feet from the injection valve do not, and neither do those for an electrode spacing of 52 feet with 52 and 75 feet between injection valve and first electrode. Further, increasing the electrode spacing at these latter values to first electrode spacings did not give improved results. It may be concluded, therefore, that with the present apparatus, the equilibrium of the main stream and the injected solution was not established before a point lying between 50 and 75 feet ( 30 to 45 diameters) downstream of the injection valve. An interesting point is the reversal of sign of the error bet-
Spencer a étudié les erreurs de mesure de débit par les bascules de laboratoire, ot les resultats de cette investigalion seront publiés ultérieurement. Sur la base de celte étude, les limites d'erreur admises avec $95 \%$ de sécurité pour ces essais et, pour une seule mesure, étaient évaluées $\grave{a} \pm 0,2 \%$ pour un débit de $509 \mathrm{l} / \mathrm{s}$, et à $\pm 0,4 \%$ pour un débit de $127 \mathrm{l} / \mathrm{s}$. En moyenne, 8 mesures successives ont été effectuées pendant chaque essai au débit supérieur, et 20 au débit inférieur. Les limites d'erreur, exprimées avec $95 \%$ de sécurité, pour les valeurs moyennes des mesures effectuées à la bascule, pouraient ainsi être présumées de $\pm 0,07 \%$ dans le premier cas et de $\pm 0,09 \%$ dans le deuxième cas. Les erreurs systématiques possibles dans l'étalonnage et lutilisation de l'installation de jaugeage de débit en laboratoire sont jugées inférieures à $\pm 0,1 \%$.

Afin de vérifier l'intervention éventuelle d'une « erreur personnelle » de lecture des enregistrements oscillographiques, deux agents de mesure différents ont analysé certains de ces enregistrements. Les différences entre les débits moyens calculés par ces deux agents, ne dépassaient pas $0,25 \%$, et ne mettaicnt aucune s erreur porsonnelle $\gg$ en évidence.

EFFet de L'INTERvalle fNTre les ÉLECTRODEs.

Si l'on prend comme critère de précision une différence ne dépassant pas $1 \%$ du débit mesuré par la bascule (hypothèse raisonnable, compte tenu des déviations standards des séries de mesures et des erreurs systématiques éventuelles), il apparait que les conditions immédiatement à l'aval de la soupape d'injection ne sont pas suffisamment stables pour fournir des résultats précis lorsque l'intervalle entre les électrodes est très faible.

Les résultats pour un intervalle de $8 \mathrm{~m}$ entre les électrodes et à des distances de la soupape d'injection de 8,16 et 23 metres, présentent tous des erreurs importantes. Par contre, les résultats pour une distance de $31 \mathrm{~m}$ entre la première électrode et la soupape d'injection ne présentent pas d'erreur importante, de mème ceux correspondant à un intervalle entre les b́lectrodes de $16 \mathrm{~m}$ et des distances de $16 \mathrm{~m}$ et de $23 \mathrm{~m}$ entre la soupape d'injection et la première électrode. Enfin, en portant l'intervalle entre les électrodes à ces derničres valeurs, jusqu'à le rendre égal aux intervalles existant entre les électrodes pendant les premiers essais, on n'a pas obtenu de meilleurs résultats. On peut donc conclure qu'avec le présent équipemenl, l'équilibre entre le courant principal et la solution injectée ne s'établissait pas avant un point situé entre 15 et 23 mètres ( 30 à 45 diamètres) à l'aval de la soupape d'injection. Un aspect intéressant est le changement de signe de l'erreur qui se produit entre, d'une part les intervalles de $8-8 \mathrm{mc}$ - 
ween the system spacing of $26-26$ feet, those of $52-26$ feet and $77-26$ leet, and the whole trend of results which increasing electrode spacing for these three spacings of injection valve and first electrode. It appears possible that a short overall system length could he found giving a small eror, but this could be misleading as there would be no guarantee that it would be satislactory for all conditions.

The shortest overall system length for accurate results was 102 feet (61 diameters) made up of 51 feet between injection valve and first electrode station, and 51 leet between electrode stations. The shortest overall length with minimum distance between electrode stations (minimum pipe volume to be measured) giving accurate results was 128 feet (77 diameters) made up of 102 feet belween injection valve and first electrode station, and 26 feet between injection electrode stations. Since in these experiments the shortest spacing which could be used was 26 feet, this does not necessarily indicate the possible absolule minimum spacing between electrodes. There appeared to be no advantage in using long spacing between electrode stations when the distance from injection valve to first electrode stalion was grealcr than the critical value. since results of the same degree of accuracy were obtained with long and short electrate spacings (ranging from 16 to 77 diameters).

EfFect of Flow Rate.

There was no significant difference between the results obtained at high and low flow rales, representing Reynolds numbers from $2.8 \times 10^{5}$ to $11.8 \times 10^{\circ}$ (velocity range 2 to 8.7 feet per second). 'This covers the lower end of the range of values likely to be found in practice.

\section{Methods of ANalysing Rrcords.}

The results from analysis of the records by the two methods illustrated in Figs. 9 and 10 show close asreement in nearly all cases, and on the cvidence so far there is little to choose between them on the grounds of accumey. The case with which evaluation can be carried out by the simplified method of Fis. 10 would seem to make it the most useful in practice.

It is worth noting, however, that in the results for short overall system spacing, the centre of area method gives the smaller errors, and it tres, el d'autre part, cenx de $16-8$ mètres et rle 23,5-8 mòtres, ainsi que la tendance globale des résultats obtenus par une augmentation de lintervalle entre les électrodes, pour ces trois intervalles compris entre la soupape d'injection et la première électrode. Ceci implique la possibilité de trouver une certaine longueur globale réduite de l'inslallation, à laquelle ne correspondrait qu'une faible erreur; mais ceci pourrait être trompeur, car on n'aurait aucune garanlie qu'une telle installation conviendrait a toutes les conditions.

La Iongueur globale minimale de l'installation fournissant des résultats précis était de 31 mètres (61 diamètres), dont $15,5 \mathrm{~m}$ entre la soupape d'injection et la première paire d'électrodes, et $15,5 \mathrm{~m}$ entre les deux paires d'électrodes. La plus faible longueur totale correspondant à l'intervalle minimal entre les paires d'électrodes (c'est-à-dire volume de conduite minimal à mesurer) fournissant des résultats précis, était de 39 mètres (77 diamètres), dont $31 \mathrm{~m}$ entre la soupape d'injection et la premiere paire d'électrodes, et $8 \mathrm{~m}$ entre les deux paires d'élcctrodes. Quoique le plus petit intervalle pouvant ìtre utilisé dans ces essais fût de $8 \mathrm{~m}$, cela n'indiquait pas forcément quel était l'esparement minimal absolu possible entre les électrodes. Un grand intervalle entre les paires d'électrodes ne paraissait présenter aucun avantage lorsque la distance entre la soupape d'injection et la première paire d'électrodes était supérieure à la valenr critique, car on avait obtenu des résullats du même ordre de précision tant avec de faibles cruavec de grands intervalles entre les électrodes (répartis entre 16 et 77 diamètres).

INFLUENCE DU DÉBIT.

Aucune différence significative n'a élé observée entre les résultats obtenus pour des grands et des faibles dibits, correspondant à des nombres de Reynolds de 2,8.10" a 11,8.10" (gamme de vitesse de 0,61 a $2,65 \mathrm{~m} / \mathrm{s}$ ). Ces valenrs correspondent à la partie inférieure de la ramme de valeurs qu'il est possible de rencontrer dans la pratique.

\section{MÉTHOdES D'ANALYSE DES FNREGISTREMENTS.}

Les résultats des analyses des enregistrements par les deux méthodes illustrces dans les figures 9 et 10 s'accordent bien dans presque tous les cas, mais jusqu'a maintenant, rien ne suggère que l'une soit plus précise que l'autre. Ya facilité avec laquelle on peut évaluer les résultats par la méthode simplifiće de la figure 10 paraît rendre celle-ci la plus utile dans la pratique.

Notons, toutefois, que pour les résultats correspondant à la disposition à faible intervalle, la méthode des centres de surface donne des erreurs moindres, ef qu'il est done possible 
may be that in this particular case it will have the advantage.

\section{Accunacy of Mrasurement.}

The results show that, subject to the limitafions mentioned above, the difference in measurements by the salt-velocity method and by the weighbridge was generally 1 per cent or less. As it seems reasonable, with results of this order, to neglect the possible weighbridge error, we can regard this figure as the error in the saltvelocity flow measurements.

The chief source of error is undoubtedly the scatter in the individual salt-velocity observalions. Standard deviations for the sets of observations ranged from 3 per cent to 0.5 per cent of the mean, the standard deviation for the whole series of experiments being 1.5 per cent. So far as can be ascertained, the scattcr is purely random, and if this is accepted, the 95 per cent confidence limits of error for the mean of 20 observations should be \pm 0.7 per cent, which accords well with the actual results, remembering the possible $\pm 1 / 4$ per cent error in pipe volume. If the accuracy is to be inproved, therefore, the scatter must be reduced. (The alternative of increasing the number of observations is usually impractical.) Random scatter which is due to errors in measuring the records should be considerably reduced by the introduction of apparatus which gives a direct indication of the time of passage (as mentioned in section 7.1 below). Scatter due to random mixing effects between the injected solution and the main stream is a much more difficult problem, and progress will depend on a close study of the behaviour of the solution after injection. Since this is also needed if overall system spacings are to be reduced, one set of experiments may serve both purposes. There remains the possibility that the scatter is due not solely to errors in measurement, but to random short-term fluctuations in now. This can be checked if instruments are available with sufficient response to detect such fluctuations. (They need not give absolute values.) A modified form of current-meter has been prepared by the Instrument Group for this purpose, which it is hoped to use in a second series of field tests at Kinlochleven.

\section{2. Fields tests.}

The system spacing used for the field test was 92 feet (28 diameters) from injection valve to qu'elle soit plus avantageuse dans ce cas particulier.

PRÉcISION DES MESURES.

Les résultats montrent que, sous réserve des limitations mentionnées ci-dessus, la différence entre les mesures, d'une part par la méthode de l'écran salé, et d'autre part par la bascule, élait généralement de l'ordre de $1 \%$ au plus. Puisqu'il paraît raisonnable, avec des résultats de cet ordre, de négliger l'imprécision possible de la bascule, nous pouvons considérer ce chifrre comme étant l'erreur affectant le jaugeage par écran salé.

La plus importante source d'erreurs est certainement la dispersion dans les mesures individuelles par écran salé. Les déviations-standards pour les séries de mesures allaient de 3 à $0,5 \%$ de la moyenne, et la dévialion standard pour toute la série d'essais était de $1,5 \%$. Pour autant que l'on puisse le déterminer, la dispersion est purement affaire de hasard, et si lon admet cette hypothèse, les limites d'erreur à $95 \%$ de sécurité, pour la moyenne de 20 mesures, devraient être de $\pm 0,7 \%$, ce qui s'accorde bien avec les résultats réellement ohtenus, compte tenu de l'errear possible de $\pm 0,25 \%$ sur le volume de la conduite. Pour améliorer la précision, il est done nécessaire de réduire la dispersion (la variante suivant laquelle on augmenterait le nombre des mesures n’est généralement pas pratique). La dispersion aléatoire découlant des imprécisions dans la mesure des enregistrements devrait être considérablement diminuce par l'introduction d'un appareil fournissant une indication directe du temps de passage (voir section 7.1 ci-ajrès). La dispersion provocuée par des efrets aléatoires de mélange entre la solution injectée et le courant principal pose un problime beaucoup plus diffele, dont la solution dépendra d'une ćlude poussce du comportement de la solution après injection. Etant donné qu'il esi nécessaire de sam voir s'il faut réduire les intervalles slobaux de linstallation, ces deux buts pourront être atteints à la fois par une même série d'essais. Il reste encore la possibilite que la disporsion ne soil pas due uniquement à des erreurs de mesure, mais à des fuctuations alcatoires, de courte durée, du débil. On peut rérifier ce dernier point si l'on dispose d'appareils de mesure ayant une rapidile fle réponse suffisante pour détecter de telles flucm luations (il n'est pas nécessaire qu'ils indiquent des valeurs absolues). L' "Instrument Gromp 》 a mis au point un modele de noulinet modifí que nous espérons utiliser dans une deuxième série d'essais industriels à Kinlochleven.

\section{2. - Essais industriels.}

Des intervalles de 28 mètres (28 diamètres) entre la soupape dinjection el la premiére élec- 
first electrode, and 88 feet ( 27 diameters) between electrode stations. This corresponded, as nearly as the site conditions permilted, to the shortest overall spacing shown by the laboratory experiments to give accurate results. Is was estimated that the error in determining the pipe volume between the two electrode stations was within $\pm 1 / 2$ per cent (95 per cent confidence).

It will be seen from Table 2 that the differences in the means and the standard deviations for the salt-velocity measurements are very similar to those found in the laboratory. Comparing current-meter and salt-velocity results, there is agreement of the order of 1 per cent or better between them, with no apparent systematic bias. A full description of the methods used for the current-meter measurements is given by Winternitz [6].

The standard deviations of the current-meter results for Test Series 1 to 4 and 6 to 8 were sufficiently small for it to be accepted that the flow was steady (though an estimate of its true value depends on a study of the systematic error in the current-meter measurements). For these series, therefore, a direct comparison of field and laboratory performance of the salt-velocity method could be made $\left(^{*}\right)$.

The laboratory findings appear to be confirmed, and the estimate that the means of sets of ten observations would give 95 per cent confidence limits of error in the mean of \pm 1 per cent borne out. The agreement between the two independent methods of measurement is very satisfactory. trode, de 27 mètres (27 diamètres) entre les paires d'électrodes, ont été utilisés pour l'essai industriel. Ils correspondent, dans la mesure oì les conditions locales le permettaient, au plus faible intervalle pouvant encore fournir des résultats précis, d'après les essais en laboratoire. On a estimé que l'imprécision dans la détermination $d u$ volume de la conduite entre les deux paires d'électrodes était de $\pm 1 / 2 \% \quad(95 \%$ de sécurité).

On voit, d'après le tableau 2 , que les différences entre les valeurs moyennes et entre les déviations standards dans les mesures par écran salé, ressemblent beaucoup à celles déterminées en laboratoire. En comparant les résultats des mesures au moulinet et par écran salé, on constate qu'ils correspondent entre eux à environ $1 \%$ près, ou mieux, apparemment sans tendance d'erreur systématique quelconque. Une description complète des méthodes utilisées pour les mesures au moulinet a été faite par Winternitz $[6]$.

Les déviations standards des résultats des mesures au moulinet pour les séries d'essais 1 à 4 et 6 à 8 étaient suffisamment faibles pour admettre que le débit était régulier (bien que l'évaluation de sa valeur réelle dépende d'une étude de l'erreur systénatique des mesures au moulinet). Il a donc été possible pour ces séries de faire une comparaison directe entre les résultats des mesures par écran salé industrielles en laboratoire $\left({ }^{*}\right)$

Les résultats obtenus en laboratoire paraissent être confirmés, ainsi que l'hypothèse que les moyennes de groupes de 10 mesures fourniraient des limites d'erreur moyenne de $\pm 1 \%$ (95\% de sécurité). Ia manière dont ces deux inéthodes de mesures différentes se confirment est très satisfaisante.

\section{6. - FURTHER DEVELOPMENTS \\ 6. - AMELIORATIONS FUTURES}

\section{1. - Direct flow indication.}

The satisfactory results obtained by using the "midpoint of half-maximum ordinates" method of analysing records (Fig. 10) suggested the possibility of eliminating the oscillograph record completely and obtaining a direct indication of

(*) It should be noted that the steadiness of the current-meter readings does not rule out the possibility of short-term random fluctualions in flow, since the observations were made over longer periods than one saltvelocity observation.

\section{1. - Indication directe des débits.}

Les bons résultats par la méthode du « point médian des ordonnées semi-maximales " pour l'analyse des enregistrements (fig. 20), ont suggéré la possibilité d'éliminer entièrement l'enregistrement par oscillographe et d'obtenir une indication directe de l'intervalle de temps carac-

(*) Notons que la régularité des indications des moulinets n'exclut pas la possibilité de fluctuations de débit aléatoires de courte durée, étant donné que les observalions se sont étendues sur des périodes plus longues que l'intervalle de temps correspondant à une seule mesure par écran salé. 


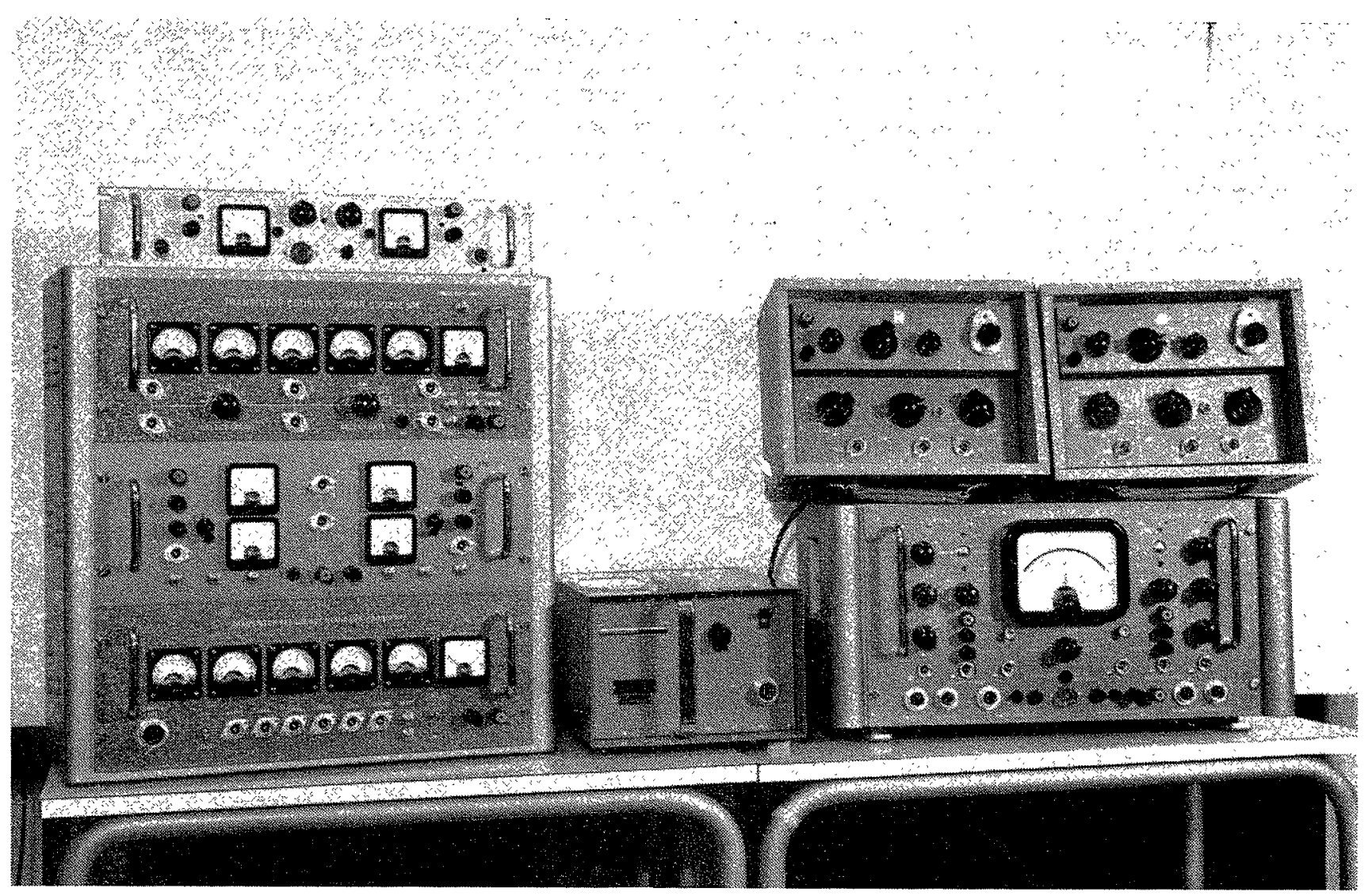

FIG. 20. Battery-operated transistor equipment for direct measurement of transit time. Appareils à transistor alimentés par batterie pour la mesure directe du temps de passage

the characteristic time interval for passage between the electrode stations. Leslie [7], devised an ingenious èlectrical circuit for accomplishing this, and apparatus has been constructed in which the required time interval is displayed on an electronic counter.

All that is necessary to determine the flow is to divide the volume of the main stream between the electrode stations by the time interval shown on the counter, so that the measurement is, for all practical purposes, instantaneous.

As the counter unit is transistor operated, all the equipment needed for the method can now be run from $30 \mathrm{v}$ batteries. Fig. 20 shows the complete detection apparatus in this form.

Preliminary trials on the laboratory pipe-line have shown very promising results, and it is proposed to use the equipment during a further series of field trials at Kinlochleven, as well as in comprehensive laboratory experiments.

\section{2. - Multiple injection apparatus.}

It will be necessary to use more than one injection valve in large pipe-lines. Experience téristique correspondant au passage entre les paires d'électrodes. Leslie [7] a mis au point un circuit électrique ingénieux pour résoudre ce problème, et un appareillage a été construit au moyen duquel l'intervalle de temps désiré est indiqué par un compteur électronique.

Pour déterminer le débit, il suffit alors de diviser le volume du courant principal entre les paires d'électrones par l'intervalle de temps indiqué sur le compteur, obtenant ainsi une mesure pratiquement instantanée, dans tous les cas pratiques.

Puisque le groupe compteur est à transistors, tous les appareils nécessaires pour cette méthode peuvent fonctionner avec des batteries de 30 volts. La figure 20 montre l'ensemble de cet appareillage de détection.

Des essais préliminaires sur la conduite de laboratoire ont fourni des résultats très encourageants, et on envisage d'utiliser l'installation pour une série d'essais industriels complémentaires à Kinlochleven, ainsi que pour des essais complets en laboratoire.

\section{2. - Dispositif d'injections multiples.}

Il faudra, dans les grandes conduites, utiliser plus d'une soupape d'injection. Il paraît, d'après 
so far suggests that pipes up to 84 inches in diameter can be covered by valves mounted from the pipe wall, but for larger sizes some internal supporting structure will probably be needed. Some of the difficulties associated with ensuring simultaneous opening of a number of valves should be overcome by the use of high-pressure gas as the actuating medium. Cartridges of adequate size and performance will be available.

It is proposed to manufacture further injection valves, and to carry out lests on multiple assemblies.

\section{3. - Measurement of channel flow.}

The experiments conducted so far have been made on pipe-lines. A channel 8 feet square is available at Kinlochleven, where it is proposed to attempt comparative flow measurements by a number of methods, including salt-velocity. This will afford an opportunity of assessing performance, and of testing a multiple injection assembly.

\section{4. - Use of short measuring lengths.}

The work described in this report has shown the limits within which reasonably accurate neasurements can be obtained with the apparatus in its present form. One possibility of improvement is to reduce the length between the electrode stations, and hence the volume of pipe or channel which has to be accurately suxveyed. It is also desirable to keep the overall test length short, so that measurements are possible on short pipe-lines or channels.

A study of the injection and mixing processes will be made, and experiments using artificial turbulence stimulators to promote mixing (which have been employed elsewhere) carried out, in order to determine the best type of installation for short test lengths. les expériences réalisées jusqu'à présent, que des soupapes montées uniquement sur la paroi de la conduite peuvent convenir pour des conduites d'un diamètre allant jusqu'à $2,13 \mathrm{~m}$, mais quelques supports internes seront sans doute nécessaires all-delà de cette dimension. Certaines difficultés d'assurer l'ouverture simultanée de plusieurs soupapes pourront ètre éliminées en employant des gaz à haule pression pour commander les soupapes. On pourra disposer de cartonches de dimensions et de puissances suffisantes.

On envisage la fabrication de soupapes d'injeclion supplémentaires et ensuite de conduire des essais sur des ensembles multiples.

\section{3. - Mesures des débits en canal.}

Jusqu'à présent, les essais ont été réalisés dans des conduites. Un canal d'une section carrée de $2,44 \times 2,44$ mètres est disponible à Kinlochleven, où l'on envisage d'essayer des mesures comparatives de débit par plusieurs méthodes différentes, y compris la méthode de lécran salé. Ceci procurern l'occasion d'apprécier les résultats et d'étudier le comportement d'un ensemble d'injections multiples.

\section{4. - Utilisation de faibles intervalles entre les électrodes.}

Les études décrites dans le présent rapport ont montré les limites dans lesquelles il est possible d'effectuer des mesures raisonnablement précises avec l'appareillage dans sa forme présente. Un des moyens possibles pour améliorer ces mesures serait de réduire l'intervalle entre les paires d'électrodes et, par suite, le volume de conduite ou de canal devant etre mesuré avec précision. II est également souhaitable de raccourcir la longueur totale de la section d'essais afin de permettre des mesures dans des conduiles ou des canaux de faible longueur.

Les processus d'injection et de mélange seront étudiés, et des expériences seront réalisées en utilisant des gencrateurs artificiels de turbulence pour faciliter le mélange (appareils déjà utilisés autre part), afin de déterminer le neilleur genre d'installation pour des troncons de mesure de faible longueur.

\section{CONCLUSIONS}

\section{CONCLUSION}

7. 1. The apparatus as finally developed has fulfilled the requirements of low weight and bulk, and has proved completely reliable in an extensive series of operations. It has been shown to give satisfactory results in water of high initial
7.1. L'appareil finalement mis au point a $\mathrm{sa}$ tisfait aux conditions de faibles poids et encombrement et s'est montré complètement sûr au cours d'une série prolongée d'opérations. Il a donné de bons résultats avec de l'ean de conduc- 
conductivity, and the type of injection mechanism used should make it possible to operate in pipe-lines under high heads.

7.2. The results of the laboratory measurements show that, subject to reasonably clearly defined limits, flow can be measured with an error not greater than 1 per cent (with 95 per cent confidence). Comparative field tests appear to confirm this under practical conditions.

7.3. Developments made during the course of the experiments have enabled apparatus to be constructed which should be capable of givins virlually instantaneous measurement of How.

7.4. Information has been obtained which will make it possible to explore further the potentialities of the method, with a view to further improvement of the present apparatus and accuracy of the results.

\section{Acknowledgements.}

The authors wish to achnowledge their indebtedness to the following:

1. Mr. R.W.W. Scott and Miss J.P. Haxton, who assisted throughout the experiments and analysed nearly all the records.

2. Mr. W.H.P. Leslie and Mr. J.J. Hunter, who designed and constructed the transistor equipment, and gave advice on electrical problems.

3. Imperial Chemical Industries Ltd., Nobel Division, Stevenston, for development work on the power cartridges and the loan of firing equipment.

4. The management and staff of the British Aluminium Company, who gave valuable assistance and co-operation during the field tests. tivité initiale élevée, et il devrait être possible, grâce au dispositif d'injection utilisé, de le faire fonctionner dans des conduites sous des charges importantes.

7.2. - Les résultats des mesures en laboratoire montrent que, dans des limites suffisamment bien définies, le débit pent être mesuré avec une erreur ne dépassant pas $1 \%(95 \%$ de sécurité). Les essais industriels comparatifs paraissent confirmer cette hypothèse dans des conditions pratiques.

7.3. - Les mises au point effectuées pendant les expériences ont permis de réaliser des appareils qui devraient pouvoir fournir des mesures de débit pratiquement instantanées.

7.4. - Des données ont été recueillies qui permettront d'explorer davantage les possibilités de la méthode, dans le but d'améliorer les appareils d'essais actuels el la précision des résultats.

\section{Remerciements.}

Les auteurs désirent remercier pour leur assistance :

1. M. R.W.W. Scott et Mlle J.P. Haxton, qui ont apporté une aide précieuse pendant toutes les expériences et qui ont analysé la quasitotalitẻ des résultats;

2. M. W.H.R. Leslie et M. J.J. Hunter, qui ont étudié et réalisé les appareils à transistors et apporté des conseils en matière électrique;

3. Les Imperial Chemical Industries Ltd, Nobel Division, Stevenson, pour leurs travaux de mise au point des cartouches et pour la mise à disposition des appareils de mise à feu ;

4. La Direction et le Personnel de la British Aluminium Company, pour son aide et sa collaboration pendant les essais industriels.

\section{REFERENCES}

11] Allen (C. E.) and Taylor (E. A.). The salt velocity method of water flow measurement.

Trans. Amer. Soc. mech. Engrs, 1923, 45, 283-341.

[2] Young (L.), McMillan (Miss C.-E.) and Scotw (R. W. W.). Salt-velocity flow measurements in a 1-ineh diameter pipe.

M.E.R.L. Fluids Note No 33. East Kilbride, Glasgow: Mechanical Engineering Research Laboratory, 1955 .

(3) Lesire (W.H.P.) and Hunter (J.J.). Transistorised general purpose equipment for mechanical measurements from zero to $1 \mathrm{kc} / \mathrm{s}$.

M.E.R.L. Finids Report (in preparation).
[4] Taylon (G. I.). The dispersion of matter in turm bulent flow through a pipe. Proc. ray. Soc., 1954, $223 \mathrm{~A}, 446-468$.

[5] Rosents (A.H.). The Loeh Leven water-power works. Min. Proc. Instn civ. Engrs, 1911, 28-73.

[6] Wenternatz (F. A.L.). Comparison of flow measuring techniques at Kinlochleven hydroelectric station. M.E.R.L. Fluids Report No. 59. East Kilbride, Glasgow: Mechanical Engineering Research Laboratory, 1957.

[7] LesLis (W.H.P.) and Hunter (J.J.). Direct digital indication of the time between the centroids of two pulses.

M.E.R.L. Fluids Report (in preparation). 


\section{APPENDIX}

LIST OF EQUIPMENT TAKEN FOR FIELD TESTS

Two electrodes.

One injection valve.

One breech and ounting bracket.

Two 100-yard drums of R.F. screened cable.

One salt-solution pump and container.

Two bridge units and malching transformers.

Two mains-operated bridge oscillator-detector units.

One double-beam oscilloscope.

One oscilloscope camera and cassettes.

Six interconnecting leads.

Two telephone sets.

One drum of telephone cable.

One box of 500 cartridges.

One box of 250 feet $35-\mathrm{mm}$ recording film.

One double-channel battery bridge oscillator-detector.

One battery frequency standard.

One high-speed four-channel pen recorded.

One box of 100 feet recording paper.

There 7-lb drums of common salt.

One salt mesure and mixing tank.

One pipe-measuring rod. .

One small box of tools.

Four developing dishes.

Two spiral reels and loader.

One centrifuge drier.

One bottle of developer.

one boltle of fixer.

MATERIAL CONSUMED DURING FIELD TESTS

310 Cartridges.

$14 \mathrm{lb}$ common salt.

Developer and fixer.

180 feet $35-\mathrm{mm}$ film.

50 feet recording paper.

\section{TIME TAKEN FOR FIELD TESTS}

Installation of equipment and measurement of pipe. 28 man-hours.

Conducting 14 test series. 12 man-hours.

Evaluation of results. 42 man-hours.

(NoTE: A three-man team carried out the work.)

\section{APPENDICE}

\section{LISTE DE L'ÉQUIPEMENT EMPLOYÉ POUR LES ESSAIS SUR PLACE}

Deux électrodes.

Uue soupape d'injection.

Une culasse et son support de montage.

Deux tambours de $91 \mathrm{~m}$ de câble blindé contre les hautes fréquences.

Une pompe à solution saline et un réservoir.

Deux groupes pont et transformateurs d'adaptation.

Deux oscillateurs en pont/détecteurs alimentés par le secteur.

Un oscilloscope à double faisceau.

Un appareil photographique pour l'oscilloscope, el cassettes.

Six câbles d'interconnexion.

Deux ensembles téléphoniques.

Un tambour de câble pour téléphone.

Une boîte de 500 cartouches.

Une boite de $76 \mathrm{~m}$ de film de $35 \mathrm{~mm}$ pour les enregistrements.

Un oscillateur en pont-détecteur à 2 voies, alimenté par batterie.

Un étalon de fréquence alimenté par batterie.

Un chronographe à 4 plumes à grande vitesse.

Une boîte de $30 \mathrm{~m}$ de papier pour enregistrements.

Trois barils de $3 \mathrm{~kg}$ chacun de sel commun.

Un bac de mélange du sel et de mesure.

Une perche à mesurer les conduites.

Une petite caisse d'outillage.

Quatre cuvettes à développer.

Deux bobines spirales et un chargeur.

Un séchoir centrifuge.

Un flacon de révẻlateur.

Un flacon de fixateur.

\section{MATIERES CONSOMMÉES PENDANT LES ESSAIS SUR PLACE}

310 cartouches.

$6,350 \mathrm{~kg}$ de sel commun :

Révélateur et fixateur.

$55 \mathrm{~m}$ de film de $35 \mathrm{~mm}$.

$15 \mathrm{~m}$ de papier enregistreur.

\section{TEMPS PASSE AUX ESSAIS SUR PLACE}

Mise en place de l'équipement et mesure de la conduite.

28 heures de travail.

Exécution de 14 séries d'essais.

12 heures de travail.

Dépouillement des résultats.

42 heures de travail.

(Nota : Une équipe de 3 hommes exécuta le travail.) 